\title{
POLICY AND PRACTICE AUDIT AND GHG REDUCTION STRATEGY RECOMMENDATIONS FOR THE CITY OF ARROYO GRANDE
}

\author{
A Project Presented to \\ the Faculty of California Polytechnic State University, \\ San Luis Obispo
}

IN PARTIAL FULFILLMENT

OF THE REQUIREMENTS FOR THE DEGREE

Master of City and Regional Planning

by

CHERYL COCHRAN

June 2012 
(C) 2012

Cheryl Cochran

ALL RIGHTS RESERVED 
TITLE:

Policy and Practice Audit and GHG Reduction Strategy Recommendations for the City of Arroyo Grande
AUTHOR:
Cheryl Cochran
DATE SUBMITTED: June 2012

COMMITTEE CHAIR: Michael Boswell, Associate Professor

COMMITTEE MEMBER: Adrienne Greve, Assistant Professor

COMMITTEE MEMBER: Kelly Heffernon, Associate Planner 


\section{ABSTRACT}

Policy and Practice Audit and GHG Emissions Reduction Strategy Recommendations for the City of Arroyo Grande

\section{Cheryl Cochran}

In preparation for a Climate Action Plan, this policy and practice audit provides an overview of current city policies and practices with the potential to impact greenhouse gas (GHG) emissions reduction goals. The audit builds upon information previously collected in a GHG emissions inventory report to identify policies that are consistent or inconsistent with emissions reductions goals. Preliminary GHG emissions reductions recommendations address policy gaps and opportunity areas in suggesting strategies to achieve GHG emissions reductions. 
List of Acronyms vii

Introduction 1

GHG Emissions Inventory Summary 5

Methodology 7

Section I: Policy Audit

Policy Audit Analysis Summary 10

Implementation Status Key 12

Federal and State Policies 13

Transportation Policies 15

Growth Management and Mixed-Use Policies 24

Buildings Policies 29

Water Policies 32

Carbon Sequestration Policies 37

Renewable Energy Policies

Potentially Inconsistent Policies 39

Section II: Recommendations

GHG Emissions Reduction Strategy Recommendations

Strategy Recommendations List

Reducing GHG Emissions from Municipal Operations 44

Transportation Recommendations 45 
Reducing GHG Emissions from Employee Commute

Reducing GHG Emissions from Municipal Vehicle Fleet 49

Buildings Recommendations 51

Reducing GHG Emissions from Municipal Buildings 51

Reducing GHG Emissions from Outdoor Lighting 53

Community-Wide Recommendations 55

Transportation Recommendations 55

Buildings Recommendations 58

Reducing GHG Emissions from Existing Buildings 58

Reducing GHG Emissions from New Buildings 59

Renewable Energy 60

Next Steps 61

References 63 


\section{List of Acronyms}

\begin{tabular}{|l|l|}
\hline Acronym & Meaning \\
\hline GHG & Greenhouse Gas \\
\hline CAP & Climate Action Plan \\
\hline IPCC & Intergovernmental Panel on Climate Change \\
\hline ARB & California Air Resources Board \\
\hline ICLEI & $\begin{array}{l}\text { International Council for Local Environmental Initiatives - } \\
\text { Local Governments for Sustainability }\end{array}$ \\
\hline CAPCOA & California Air Pollution Controls Officers Association \\
\hline LED & Light-Emitting Diode \\
\hline CSI & California Solar Initiative \\
\hline PMC & Pacific Municipal Consultants \\
\hline PEV & Plug-in Electric Vehicle \\
\hline
\end{tabular}




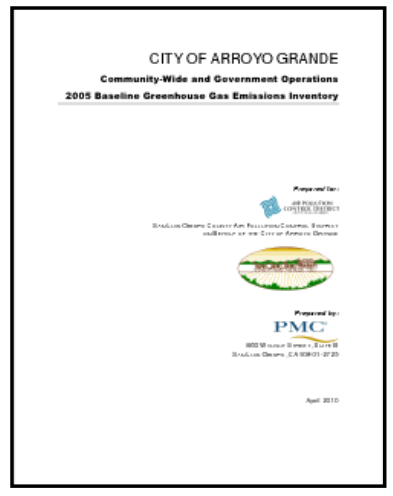

The policy and practice audit builds on the information obtained from the GHG Emissions Inventory Report.

\section{Policy and Practice Audit}

In preparation for the development of a Climate Action Plan, the City of Arroyo Grande ("the City") has completed a greenhouse gas (GHG) emissions inventory for both community-wide and municipal operations. Section I of this project report provides further background information on policies and practices in the City of Arroyo Grande that have the potential to impact GHG emissions reduction goals and strategies. A policy and practice audit can help the community understand which policies support or conflict with reductions strategies, and what actions the community might already be taking that can influence GHG reduction goals. This analysis is intended to provide a more comprehensive and detailed understanding of the current situation and to facilitate the creation of GHG emissions reduction strategies.

Since the GHG emissions inventory report was completed with baseline year 2005, the examination of city practices focused on identifying policies implemented and changes made since 2005 that could impact emissions. The audit also identifies policies with the potential to affect emissions through their continued implementation in the coming years.

\section{GHG Emissions Reduction Strategies}

Section II of this document provides recommendations for GHG reduction strategies. Strategies were chosen based on their potential to reduce emissions from areas with the highest percentages of emissions (transportation, buildings) and their potential to address policy gaps. For instance, strategies focus more on alternative commute incentive programs instead of improvements to bicycle and pedestrian infrastructure because the city is already in the process of developing improvements to bicycle and pedestrian infrastructure. Additionally, recommendations focus more on strategies to reduce emissions from municipal operations because the city has more control over these practices, and can leverage the opportunity to provide a framework and examples for community-wide development of similar strategies. 


\section{Climate Change}

The global scientific community recognizes Climate Change as a serious threat to public health and safety and economic stability. The average temperature of the Earth's surface has increased by about 1.2 to $1.4^{\circ} \mathrm{F}$ since 1900 , and other aspects of the climate are also changing such as precipitation patterns and storminess (US Environmental Protection Agency). The Intergovernmental Panel on Climate Change (IPCC) Climate Change 2007 synthesis report states "Most of the observed increase in global average temperatures since the mid20th century is very likely due to the observed increase in anthropogenic GHG concentrations. It is likely that there has been significant anthropogenic warming over the past 50 years averaged over each continent (except Antarctica)." Greenhouse gasses make life as we know it possible by absorbing much of the energy from the sun, energy that is then radiated to the earth's surface, making the planet about $60^{\circ} \mathrm{F}$ warmer than it would be otherwise (US Environmental Protection Agency). The large amount of greenhouse gasses added to the earth's atmosphere from human activities in the past century is enhancing the natural greenhouse effect, and threatening many aspects of human and environmental health. Potential harmful effects of climate change vary by region and stem from extreme weather events, changes in sea level, reduced water supplies, and ecosystem disruption.

\section{Greenhouse Gasses}

Greenhouse gasses include carbon dioxide, methane, nitrous oxide, sulfur hexafluoride, chlorofluorocarbon, and hydro-chlorofluorocarbon (County of San Luis Obispo Energy Wise Plan, 2011). As the greenhouse gas that is released in the highest quantities in most urban areas, carbon dioxide is of greatest concern in most GHG reduction strategies. Assembly Bill 32 (AB32) set a statewide goal of reducing GHG emissions levels to 1990 levels by 2020 .

\section{Climate Change Impacts in California}

California is already experiencing impacts from climate change, including increased average temperatures, more extreme hot days, and fewer cold nights. Sea levels along the coast have risen by as much as seven inches, increasing erosion and pressure on the state's infrastructure, water supplies, and natural resources. Shifts in the water cycle are seen in less winter precipitation falling as snow, and both snowmelt and rainwater running off sooner in the year $(2009$ California Adaptation Strategy). The 2009 California Adaptation Strategy identifies a variety of specific threats to the following areas:

Agriculture: More frequent and severe droughts, less water stored in the Sierra snowpack, increased pests and invasive species, and heat waves.

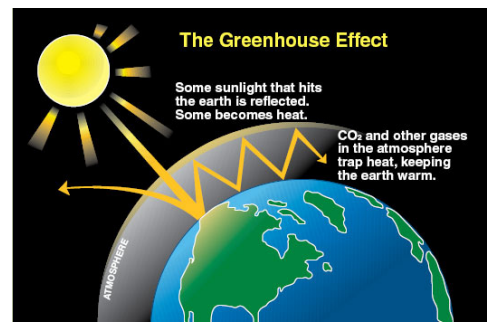

Greenhouse gasses in the atmosphere trap heat. 


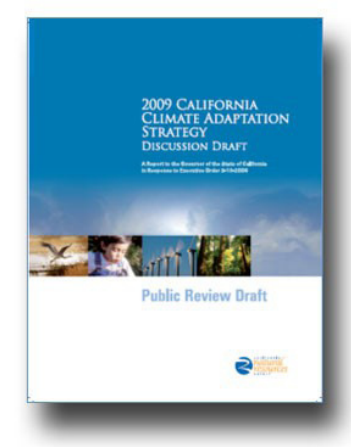

The 2009 California Adaptation Strategy provides an overview of climate change impacts facing California.
Biodiversity: Effects on habitat, availability and timing of food supply, temperatures, extreme climate events such as floods and fires, and other changes.

Forests: Increased fires, drought, invasive species, and more.

Ocean and Coastal Resources: Sea level rise is expected to increase at a faster rate in coming decades, threatening coastal development, beach and shoreline erosion, flooding during storm surges, impacts to fisheries and wildlife, loss of recreation and tourism opportunities, and more.

Public Health: Climate Change poses risks to public health and safety due to increased heat waves and associated air pollution, increased fires and associated air and water pollution, introduction of new diseases, pests and invasive species, impacts to agriculture and water supplies, and more.

Energy and Transportation: Direct impacts from heat waves, floods, fire, sea level rise, and storm surges. Longer term changes will impact power supplies, the electric grid, pipelines, airports, seaports, roads, and highways.

\section{Local Governments' Role in Addressing Climate Change}

The California Air Resources Board (ARB) states on their website that local governments have an important role to play in meeting California's GHG reduction goals due to their broad influence and authority over activities that contribute to direct and indirect GHG emissions. "California's AB 32 Scoping Plan encourages local governments to adopt a GHG emissions reduction goal consistent with the State's overall goal of reducing Statewide emissions to 1990 levels by 2020 (an approximate 15\% reduction from today's levels). However, since 1990 data on a jurisdictional level may not be available, ARB suggests that local governments set their targets based on today's levels, using the most current and best available GHG emissions data for their jurisdictions."

Planning is an appropriate field to address climate mitigation due to its long-range outlook, comprehensive prospective, and affinity for consensus building (Shuford, S., Rynne, S., Mueller, J. 2010). Climate Action Plans (CAPs) have emerged in over 120 cities and counties as strategies for reducing GHGs (Boswell, Greve, \& Seale 2012). Additionally, climate mitigation strategies often have secondary benefits to the local community, including stimulating the economy, improving air quality, improving public health, and reducing healthcare costs. (ICLEI Milestone Guide). 
Climate Planning in Arroyo Grande

This project is intended to better prepare the City of Arroyo Grande to address climate change at the local level by providing neces-

sary background information and preliminary recommendations. Although strategies for preparing CAPs vary, most cities that have prepared a CAP have followed ICLEI's Cities for Climate Protection Milestone Guide (Boswell, Greve, \& Seale, 2012). The guide consists of five milestones:

1. Conducting a baseline emissions inventory and forecast

2. Setting an emissions reduction target

3. Developing an action plan to meet the target

4. Implementing actions in the plan; and

5. Monitoring and verifying emissions reduction progress

The City of Arroyo Grande has completed a GHG Emissions Inventory Report for baseline year 2005 including a forecast through 2025 for a business-as-usual approach. Next steps might include setting an emissions reduction target and developing an action plan to meet the target.

Addressing Climate Change at the local government level is often accomplished by a CAP. In "Local Climate Action Planning", Boswell Greve and Seale (2012) describe CAPs as "strategic plans that establish policies and programs for reducing (or mitigating) a community's greenhouse gas (GHG) emissions and adapting to the impacts of climate change".

The City intends to complete a CAP in the future. It remains to be decided whether the CAP will be a stand-alone document, or incorporated into the General Plan. Regardless, evaluating current City plans and policies is an important first step in preparing to complete a CAP. Although the ICLEI Milestones do not include a policy audit, it is one of "several embedded or additional steps that are critical to the CAP process" (Boswell, Greve, \& Seale 2012). Boswell, Greve, and Seale break down the CAP process into three steps, Phase I: Preliminary Activities, Phase II CAP Development, and Phase III, Implementation and monitoring. Phase I is further divided as follows:

Phase I: Preliminary Activities

1. Establish community commitment

2. Build community partnerships

3. Establish the role of the plan

4. Assemble a Climate Action Team

5. Consider the logistics of plan development

6. Establish a public education and outreach campaign

7. Audit existing community policies and programs 
Section I of this document is intended to provide step 7: Audit existing community policies and programs. Boswell, Greve, and Seale (2012) explain that the policy audit "allows a community to clearly identify gaps in its current policy and program framework.” Information gathered from the policy audit was used to construct the recommendations in section II of this report, and can be used to provide an accurate understanding of the current situation for further climate planning efforts. Section II of this document, GHG Emissions Reduction Strategy Recommendations, provides preliminary recommendations that can be further developed in the Climate Action Plan.

\section{GHG Emissions Inventory Summary}

In 2010, PMC prepared a Baseline Greenhouse Gas Emissions Inventory for the Air Pollution Control District on behalf of the City of Arroyo Grande. 2005 was chosen as the baseline year because the most complete data was available for that year. The inventory provides the GHG emissions quantities from various sectors community-wide, and for those specifically from municipal operations.

\section{Community-Wide GHG Inventory Results}

The inventory, produced by PMC, reported:

The total community of Arroyo Grande emitted approximately 96,549 metric tons of carbon dioxide equivalent $(\mathrm{CO} 2 \mathrm{e})$ in the baseline year 2005. The transportation sector was by far the largest contributor to emissions (57.0\%), producing approximately 55,030 metric tons of

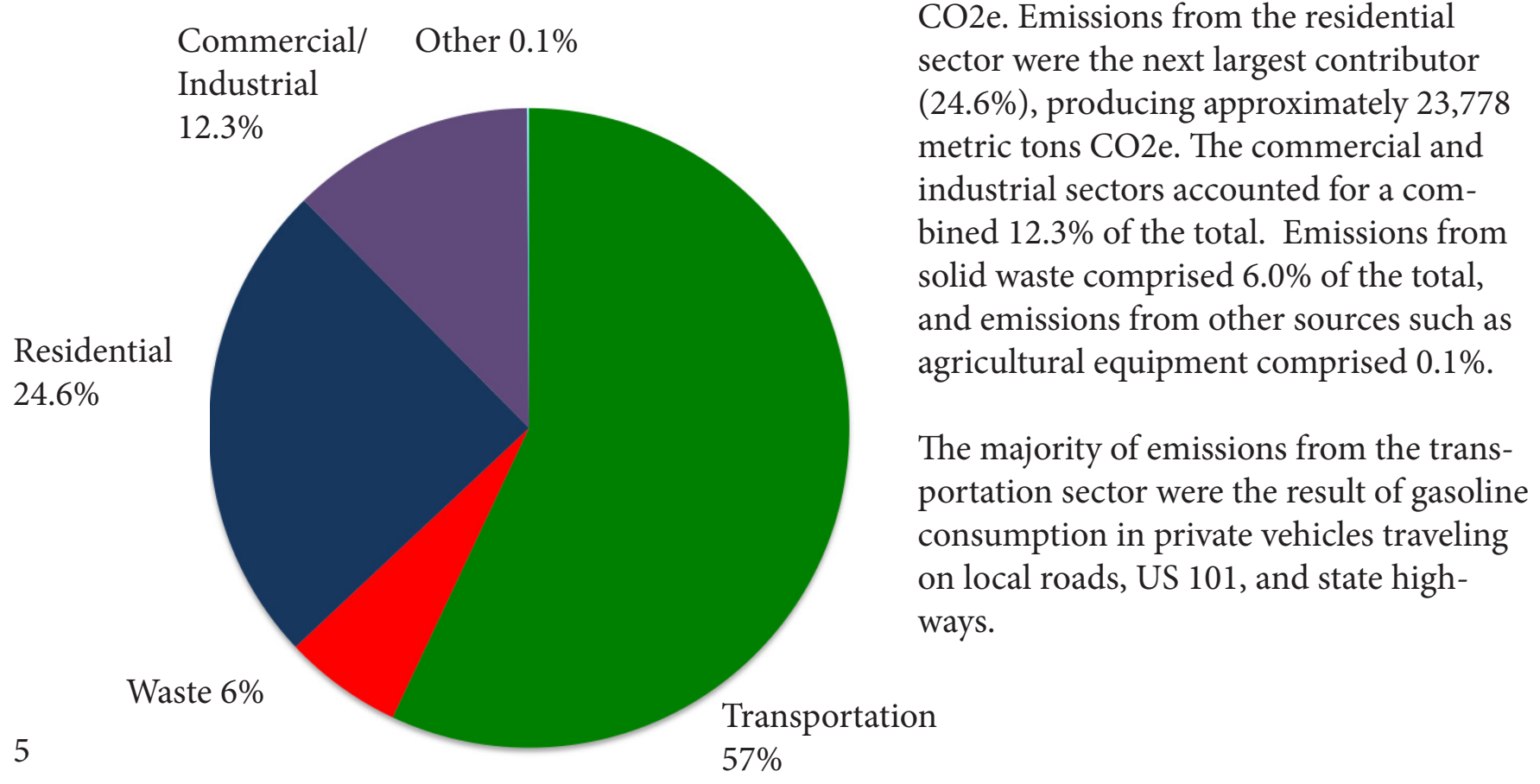

$\mathrm{CO} 2 \mathrm{e}$. Emissions from the residential tributor (24.6\%), producing approximately 23,778 metric tons CO2e. The commercial and industrial sectors accounted for a combined $12.3 \%$ of the total. Emissions from solid waste comprised $6.0 \%$ of the total, and emissions from other sources such as agricultural equipment comprised $0.1 \%$.

The majority of emissions from the transportation sector were the result of gasoline consumption in private vehicles traveling on local roads, US 101, and state highways. 


\section{Municipal Operations Inventory}

GHG emissions from City government operations accounted for $0.1 \%$ of total community-wide emissions, approximately 994 metric tons. Fuel consumption by the city vehicle fleet was the largest contributor to the city's emissions (34.6\%). Emissions resulting from fuel consumption from employee commutes was the second largest contributor (25.5\%). Other sources of emissions include buildings, waste, streetlights and traffic signals, energy consumption from water and wastewater facilities, and miscellaneous equipment.

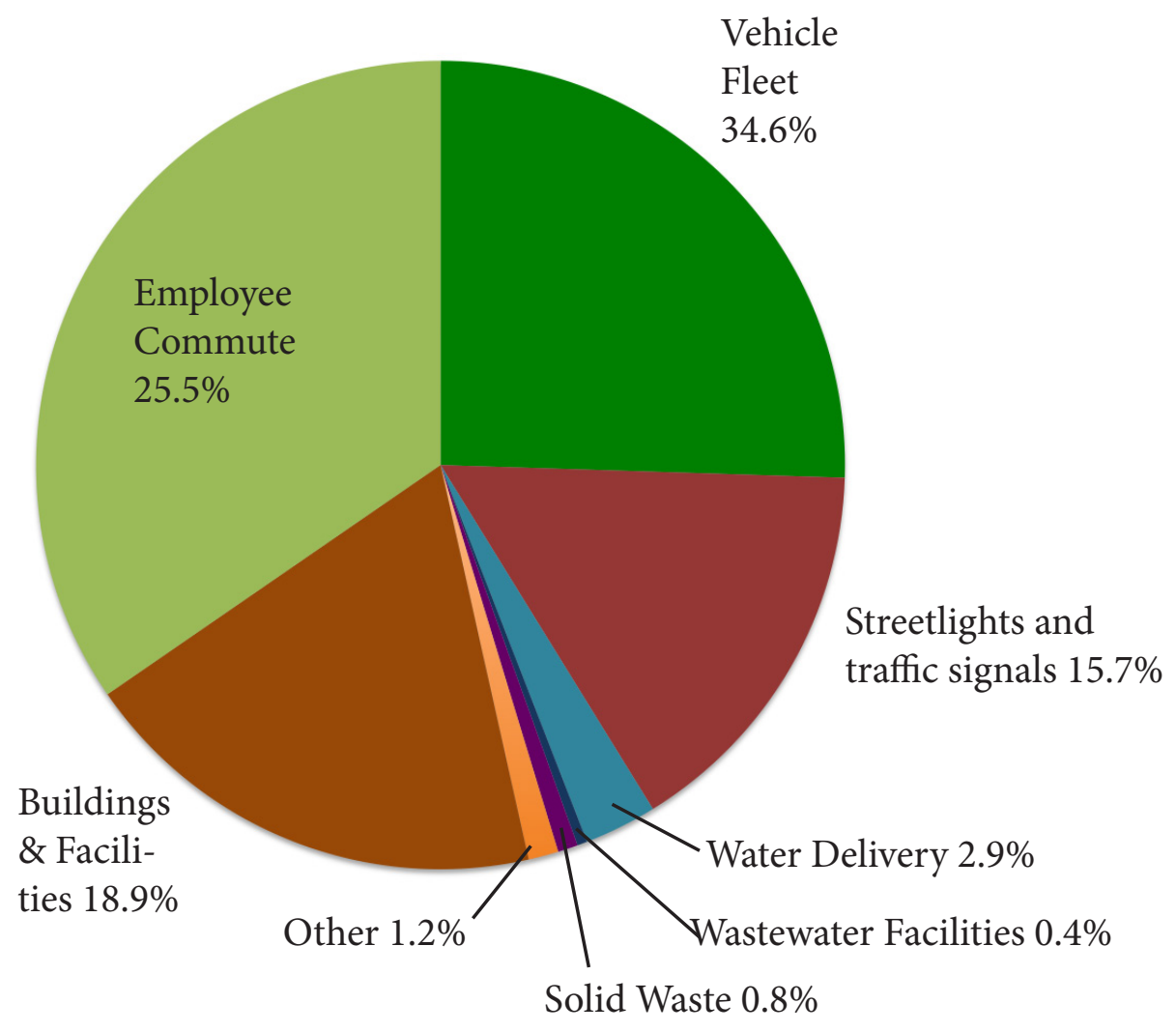

The inventory clearly establishes fuel consumption from vehicle travel as the largest source of emissions. This is true both community-wide and in municipal operations. Personal vehicle use can be attributed to many factors, including the primarily residential nature of the City, which results in many commutes to work from Arroyo Grande, the rural atmosphere, which means that services and employment may not be in close proximity to residential areas and centers of employment, and infrastructure designed primarily to serve vehicle travel. Examining the City's policies can offer a better look at how the City can begin to change commuting behaviors.

Energy consumption from residential structures was the second largest source of emissions community-wide, and commercial and industrial energy use was the next largest source. Energy consumption in buildings and facilities was also the third largest source of emissions from municipal operations. This suggests that Arroyo Grande may have significant opportunity to reduce emissions by increasing energy efficiency in buildings and developing renewable energy generation. 


\section{Methodology}

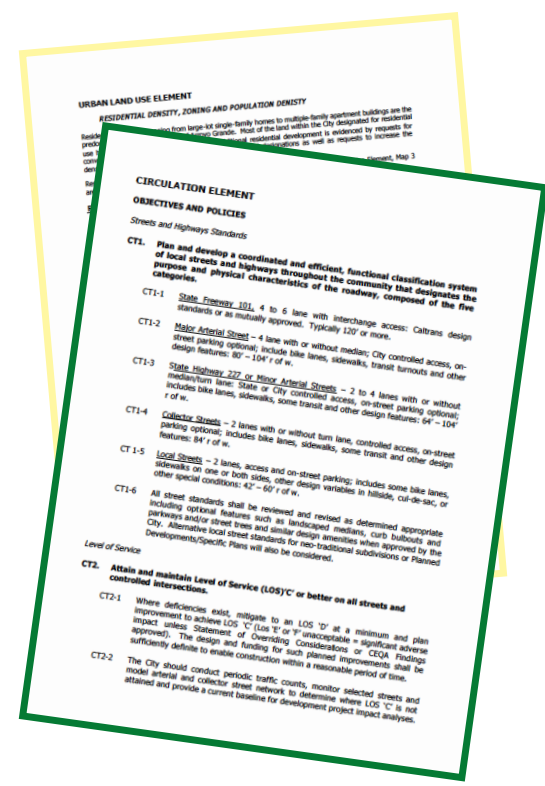

\section{City Documents Reviewed}

The following City documents were reviewed to identify policies consistent with or inconsistent with GHG emissions reduction goals, and in some cases to evaluate progress toward implementation. Documents for review were chosen based on recommendations from city staff, and those generally known to influence growth patterns, transportation options, energy use, and water consumption.

- City of Arroyo Grande General Plan

- City of Arroyo Grande Bike Plan

- City of Arroyo Grande Community-Wide and Government Operations 2005 Baseline Greenhouse Gas Emissions Inventory

- Draft City of Arroyo Grande Bicycle and Trails Master Plan Sections 1 and 2

- City of Arroyo Grande Municipal Code

- City of Arroyo Grande Public Review Draft Housing Element

- City of Arroyo Grande Urban Water Master Plan

- Cash for Grass, Existing Home Conversions Rebate Program Application

\section{Criteria for Policy and Practice Audit}

The criteria for review of City policies was developed based on emissions sources from the GHG Emissions Inventory, a review of climate literature and existing climate action plans, and policy audits conducted as part of background reports for climate action plans in other cities (see references). Prior to beginning the review process, criteria for each of the areas listed below was developed as follows. Note that a more detailed explanation of how policies in each area can influence emissions is provided with each section. Not all of the following types of policies were found to exist in the City of Arroyo Grande. Identified policies are listed and summarized in each section.

Transportation:

Policies or practices that improve or encourage public transportation, improve bicycle and pedestrian infrastructure, encourage commuting by alternative modes, development and use of alternative fuels, and reduced traffic at intersections were considered consistent with GHG emissions reduction goals. 
Growth Management:

Policies that encourage mixed-use, improve the jobs/housing balance, encourage density/compact development, and decrease parking requirements were considered consistent with GHG emissions reduction goals.

Buildings:

Policies designed to encourage energy efficiency in residential, commercial, and municipal buildings, encourage the use of renewable and recycled building materials, and promote sustainable design were considered consistent with GHG reduction goals.

\section{Water:}

Policies designed to conserve water, promote the use of reclaimed water, or improve energy efficiency in the water delivery and treatment process were considered consistent with GHG emissions reduction goals.

Solid Waste:

Policies designed to reduce the amount of waste in the community, encourage recycling or composting, and promote methane capture were considered consistent with GHG reduction goals.

Carbon Sequestration:

Policies designed to preserve or create parks and open space, and to facilitate tree and vegetation planting were considered consistent with GHG reduction goals.

\section{Process}

Each document was carefully reviewed and individual policies meeting the criteria were highlighted and later listed in a table with the name of the document, the policy title, and the policy text or a summary of the policy text. Separate tables were created for each of the categories listed above. During the review process, policies found inconsistent with the listed criteria were also highlighted and listed in separate tables.

\section{Evaluating City Practices}

An examination of City practices was conducted based on the results of the GHG Emissions Inventory Report and the policy audit. Questions as to the implementation status of some policies were developed during the review process. This information is necessary to determine potential changes in GHG emissions since the baseline year, and to evaluate which policies have been successful at achieving desired results. Other questions sought to determine whether any major changes had been made in the largest emissions sectors. For example, it was important to determine whether the City had a process for vehicle fleet turnover and had considered high efficiency vehicles or alternative fuels, and whether parking in the City is free or priced.

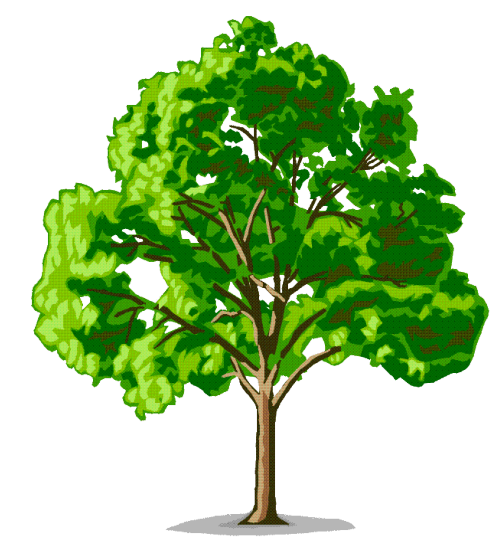

Policies that encourage tree planting are consistent with GHG emissions reduction goals. 


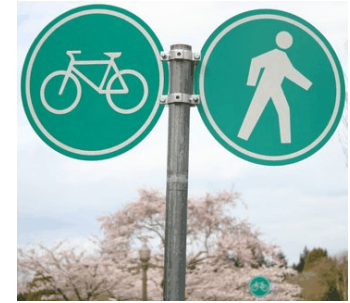

Interviews with City staff were conducted both over the phone and in person. Additional information was exchanged via email. Primary contacts included the City's Director of Recreation and Maintenance Services, the Maintenance Yard Manager, and the Community Development Department.

Information collected in these interviews was used to provide the "implementation" or "practices" section of each category when relevant information was discovered. Discussions with City staff were also taken into consideration when developing the Recommendations Section to determine for which areas with the potential for GHG reduction strategies the City would find more information beneficial.

\section{Recommendations:}

Recommendations for GHG emissions reduction strategies were chosen and developed based on perceived policy gaps, suggestions from City staff, and research on strategies currently in place in other municipalities.

Arroyo Grande is in the process of improving bicycle and pedestrian infrastructure. 


\section{Section I: Policy Audit}

Policy Audit Analysis Summary

The policy and practice audit revealed that many policies in Arroyo Grande already have the potential to address GHG reduction policies. Categories with the most policies in place that are consistent with GHG reduction goals are bicycle and pedestrian infrastructure, growth management, mixed-use development, and water conservation. Main opportunity areas identified include promoting alternative transportation, increasing energy efficiency in buildings, and developing renewable energy generation programs.

\section{Federal and State Policies}

Several recent federal and state policies mandate increases in energy efficiency or fuel efficiency, which will result in reduced GHG emissions in the City. Additionally, policies that encourage local renewable energy generation make it more likely that a higher percentage the City's power will come from renewable sources in the future.

\section{Transportation}

Based on current policies and the development of the new Bicycle and Trails Master Plan, the City of Arroyo Grande is making progress toward improving bicycle and pedestrian infrastructure. This will make bicycling and walking a more convenient and safer commute option for City residents. These policies are especially important in reducing GHG emissions since the transportation sector accounted for $57 \%$ of community-wide emissions. Providing adequate infrastructure is the first step in making bicycling and walking an attractive option for commuters. Programs to incentivize and encourage commuting by these modes were not found to be abundant in Arroyo Grande. Although the City has policies that call for encouraging employers to provide incentives for commuting by alternative modes and regional resources through organizations such as Rideshare and the Bicycle Coalition are available, the City could potentially achieve GHG emissions reductions by taking a more aggressive approach to promoting alternative transportation. 


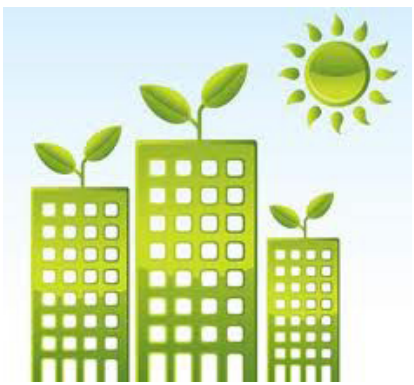

Some current city policies can help reduce emissions from buildings, but these policies could use stronger implementation programs.

\section{Growth Management and Mixed-Use}

Many policies in the City's Land Use, Housing, and Agriculture, Open Space and Conservation Elements promote development types that can reduce GHG emissions through reduced vehicular travel when destinations are in close proximity and through preserving open space, which can help sequester carbon. Existing policies that promote higher density, affordable housing and transit oriented development are also consistent with GHG emissions reduction goals.

The City also has some policies that are inconsistent with GHG emissions reductions goals. These policies limit density and building height. Although these policies are important in preserving the rural character of Arroyo Grande, they have the potential to limit the kind of development that reduces vehicle miles traveled as the City grows.

\section{Buildings}

The City has some policies that indicate an interest in developing energy efficiency programs for existing residential structures. These policies have the potential to reduce emissions from residential buildings, which accounted for $24.6 \%$ of community-wide emissions. Currently, implementation appears to be lacking in this area. Strengthening policies and programs to promote energy efficiency of both residential and commercial structures is an area of opportunity for GHG emissions reduction strategies. The City's continued efforts to improve energy efficiency in municipal operations can serve as an example to the community.

Although the City has a few policies that address maximizing building orientation and landscaping to aid in climate control, Arroyo Grande does not currently have any green building programs. The City does have a memorandum of understanding with SLO Green Build, and the City's website expresses an interest in developing green building programs in the future. Such programs could help minimize GHG emissions resulting from new construction.

\section{Water}

The City has implemented multiple water conservation programs, which have achieved measurable savings. These policies indirectly reduce GHG emissions by reducing the amount of energy used to pump and treat water. 


\section{Carbon Sequestration}

The City's Community Tree Program, the Tree Guild of Arroyo Grande, the Arroyo Grande in Bloom organization, and some General Plan policies help to plant trees and maintain vegetation and open space, which sequesters carbon and reduces the community's overall GHG emissions totals. Continuing to incorporate vegetation in new development and preserving open space can further benefit the City's GHG emissions reduction goals.

\section{Renewable Energy}

Arroyo Grande currently does not have policies likely to significantly to facilitate increased renewable energy generation. Development of policies and programs in this area represents an opportunity to potentially achieve significant GHG emissions reductions from energy consumption.

\section{Implementation Status}

Policy implementation status is indicated by he color in the right most column of each table. Implementation status is an important consideration in developing strategies to address GHG emissions. For example, policies that are consistent with GHG emissions reductions goals but are not currently being implemented might be good candidates for improved implementation strategies.

Implementation Status Key:

\begin{tabular}{|l|l|}
\hline Ongoing & \\
\hline Implemented & \\
\hline Not Yet Implemented & \\
\hline $\begin{array}{l}\text { Partially Implemented/In } \\
\text { progress }\end{array}$ & \\
\hline Undetermined & \\
\hline
\end{tabular}




\section{Federal and State Policies}

Since 2005, the baseline for Arroyo Grande's GHG Emissions Inventory Report, the federal and state government have enacted policies that may impact GHG emissions in the City of Arroyo Grande. These policies should be taken into account when developing GHG emissions reduction goals and strategies to ensure consistency and because they may already result in direct or indirect emissions reductions in some areas, thereby calling for a different focus or approach in proposed strategies.

\section{Energy and Fuel Efficiency}

Table 1: Federal and State Policies for Energy and Fuel Efficiency

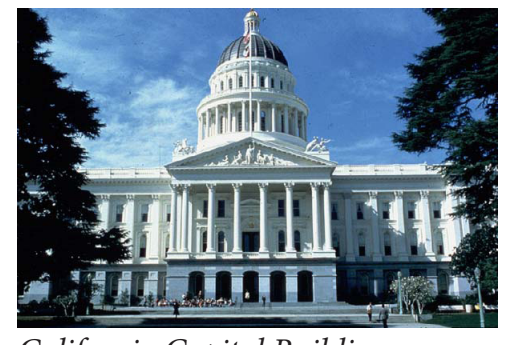

California Capital Building

\begin{tabular}{|c|c|}
\hline Title & Description \\
\hline $\begin{array}{l}\text { The Energy Independence, } \\
\text { Clean Air, and Climate Secu- } \\
\text { rity Act of } 2007 \\
\text { (Federal Policy) }\end{array}$ & $\begin{array}{l}\text { Increases the national corporate } \\
\text { average fuel economy standards. }\end{array}$ \\
\hline $\begin{array}{l}\text { CA AB } 1493 \text { Pavley Bill } \\
\text { (State Policy) } \\
\text { Year Enacted: } 2002\end{array}$ & $\begin{array}{l}\text { Requires the Air Resources } \\
\text { Board to develop regulations to } \\
\text { reduce GHG emissions from ve- } \\
\text { hicles sold in California. Amend- } \\
\text { ments adopted by the ARB in } \\
2009 \text { provide manufacturers with } \\
\text { new compliance flexibility for } \\
2012 \text { through } 2016 \text { while still } \\
\text { reducing new passenger vehicle } \\
\text { GHGs. }\end{array}$ \\
\hline $\begin{array}{l}\text { E.O. S-01-07 Low Carbon } \\
\text { Fuel Standard } \\
\text { (State Policy) } \\
\text { Year Enacted: } 2007\end{array}$ & $\begin{array}{l}\text { Requires a } 10 \% \text { reduction in } \\
\text { GHG emissions from transpor- } \\
\text { tation fuels by } 2020 \text { through } \\
\text { cleaner fuels. Expected to qua- } \\
\text { druple the use of low carbon } \\
\text { biofuels and increase alternative } \\
\text { and hybrid vehicles. }\end{array}$ \\
\hline $\begin{array}{l}\text { CA SB } 375 \text { Sustainable } \\
\text { Communities Strategy } \\
\text { (State Policy) } \\
\text { Year Enacted: } 2008\end{array}$ & $\begin{array}{l}\text { Requires California's } 18 \text { metro- } \\
\text { politan planning organizations } \\
\text { (MPOs) to develop and adopt } \\
\text { "Sustainable Community Strate- } \\
\text { gies" in the form of regional land } \\
\text { use blueprints. }\end{array}$ \\
\hline $\begin{array}{l}\text { CA Title } 24 \\
\text { Energy Efficiency Standards } \\
2008 \\
\text { (State Policy) }\end{array}$ & $\begin{array}{l}\text { Amendments to California's en- } \\
\text { ergy efficiency standards require } \\
\text { new residential and commercial } \\
\text { buildings to increase efficien- } \\
\text { cies for roofing, mechanical and } \\
\text { pool equipment, and indoor and } \\
\text { outdoor lighting. }\end{array}$ \\
\hline
\end{tabular}




\section{Renewable Energy}

Table 2: State Policies for Renewable Energy

\begin{tabular}{|l|l|l|}
\hline Title & Description \\
\hline CPUC Decision 06-01-024 and & $\begin{array}{l}\text { Offers financial incentives } \\
\text { for solar installations based } \\
\text { on electrical output of the } \\
\text { system. }\end{array}$ & $\begin{array}{l}\text { Year Enacted: 2006 } \\
\text { Portfolio Standards }\end{array}$ \\
Year Enacted: 2002 & $\begin{array}{l}\text { Expanded in 2011 under } \\
\text { Senate Bill 2 to require inves- } \\
\text { tor-owned utilities, electric } \\
\text { service providers, and com- } \\
\text { munity choice aggregators to } \\
\text { increase procurement from } \\
\text { eligible renewable energy } \\
\text { resources to 33\% of total } \\
\text { procurement by 2020. }\end{array}$ \\
\hline $\begin{array}{l}\text { CA SB 107 Public Interest En- } \\
\text { ergy Research, Demonstration, } \\
\text { and Development Program }\end{array}$ & $\begin{array}{l}\text { Requires investor owned } \\
\text { utilities such as Pacific Gas } \\
\text { and Electric, Southern Cali- } \\
\text { fornia Edison and San Diego } \\
\text { Gas and Electric to have 20 } \\
\text { percent of its electricity come } \\
\text { from renewable sources by } \\
\text { 2010. }\end{array}$ \\
\hline $\begin{array}{l}\text { CA AB 811 Municipal Clean } \\
\text { Energy Program }\end{array}$ & $\begin{array}{l}\text { Also called "Property As- } \\
\text { sessed Clean Energy (PACE)" } \\
\text { programs, allows local } \\
\text { governments to offer sustain- } \\
\text { able energy projects loans } \\
\text { to eligible property owners } \\
\text { through a voluntary assess- } \\
\text { ment on their property tax } \\
\text { bills. Assessments are perma- } \\
\text { nently fixed to the property } \\
\text { to decrease financial risk for } \\
\text { property owners. }\end{array}$ \\
\hline
\end{tabular}

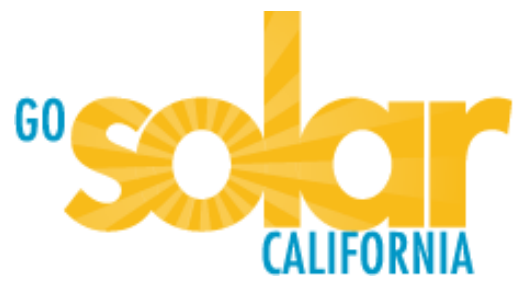

The California Solar Initiative Program offers incentives for solar installations. 


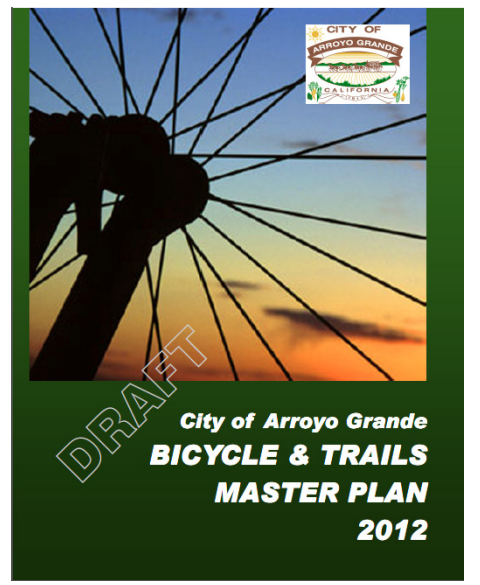

Arroyo Grande's new Bicycle and Trails Master Plan is expected to provide further improvements to bicycle and pedestrian infrastructure.
Transportation accounts for $57 \%$ of greenhouse gas emissions in Arroyo Grande. Travel on local roads within the City accounted for $75.7 \%$, and highway travel accounted for $24.3 \%$, of greenhouse gas emissions from the transportation sector. Strategies to reduce GHG emissions from the transportation sector include changes to land use patterns that reduce the length of vehicle trips, use of more fuel efficient vehicles, and encouraging bicycling, walking, and public transit use as alternatives to driving.

\section{Bicycle and Pedestrian Circulation}

Improvements to bicycle and pedestrian infrastructure make travel by these modes safer and more convenient for the public. Greater use of bicycling and walking as a form of transportation can result in a decrease in the amount of trips made by driving and the associated GHG emissions. Improvements range from new bike lanes and bike paths to requiring pedestrian scale elements that can make walking more enjoyable.

The City of Arroyo Grande adopted a Bike Plan in 2006, and is currently developing the Bicycle and Trails Master Plan to build upon those efforts and develop a comprehensive system of bikeways and pedestrian facilities. Efforts completed as a result of the Bicycle and Trails Master Plan will likely further improve bicycle infrastructure and result in a decrease in GHG emissions.

\section{Pedestrian Atmosphere and Linkage Improvements}

Existing City Policies in Table 3 contribute to a more pleasant pedestrian atmosphere and/or improved sidewalk linkages between buildings. Pedestrian scale elements such as outdoor seating and dining can make walking feel more enjoyable and safe. This can contribute to increased trips made by walking instead of driving and potentially eliminate the GHG emissions that would be associated with these vehicle trips. Some of these policies also locate frequent destinations in places with main access to arterial or collector streets, which can help reduce vehicle travel on local roads and reduce total vehicle miles traveled within the City. 
Table 3: Pedestrian Atmosphere and Linkage Improvements

\begin{tabular}{|c|c|}
\hline Source & Title and Description \\
\hline $\begin{array}{l}\text { Land Use } \\
\text { Element }\end{array}$ & $\begin{array}{l}\text { LU4-2 The Office classification shall compliment, and } \\
\text { not conflict with, adjoining development features } \\
\text { such as pedestrian oriented plazas, landscaped street } \\
\text { yards, and off-street parking areas, outdoor seating, } \\
\text { fountains and similar amenities are encouraged. The } \\
\text { maximum floor are ration (FAR) shall be } 0.5 \text {. }\end{array}$ \\
\hline $\begin{array}{l}\text { Land Use } \\
\text { Element }\end{array}$ & $\begin{array}{l}\text { LU6-6 The Village Core encourages the development } \\
\text { of outdoor dining and other similar uses provided } \\
\text { that they do not impede pedestrian use of the side- } \\
\text { walks. }\end{array}$ \\
\hline $\begin{array}{l}\text { Land Use } \\
\text { Element }\end{array}$ & $\begin{array}{l}\text { LU6-6 Prohibit drive-through commercial structures } \\
\text { and other commercial uses dependent on direct auto- } \\
\text { motive access and disruptive to pedestrian orientation } \\
\text { in the Village Core. }\end{array}$ \\
\hline $\begin{array}{l}\text { Land Use } \\
\text { Element }\end{array}$ & $\begin{array}{l}\text { LU6-9 Extend the Village Core (VC) designation } \\
\text { along Station Way and Traffic Way. } \\
\text { LU6-9.1 Maintain a distinctive visual and physical } \\
\text { environment for the southern gateway streetscape in } \\
\text { accordance with the Design Guidelines for the Arroyo } \\
\text { Grande Village. These include the use of consistent } \\
\text { street trees, landscape (planters), street furniture } \\
\text { (benches, trash receptacles, news racks, etc.), street } \\
\text { and crosswalk paving, curb, sidewalk and landscape } \\
\text { bulbouts, pedestrian-scaled lighting, identification } \\
\text { and directional signage, and other appropriate pedes- } \\
\text { trian scale elements. }\end{array}$ \\
\hline $\begin{array}{l}\text { Land Use } \\
\text { Element }\end{array}$ & $\begin{array}{l}\text { LU 6-5 Village Core developments shall emphasize } \\
\text { uses that contribute to the vitality of the whole, creat- } \\
\text { ing pedestrian traffic and interest, as outlined in the } \\
\text { Design Guidelines for the Arroyo Grande Village. }\end{array}$ \\
\hline $\begin{array}{l}\text { Land Use } \\
\text { Element }\end{array}$ & $\begin{array}{l}\text { LU6-6 The Village Core encourages the development } \\
\text { of outdoor dining and other similar uses provided } \\
\text { that they do not impede pedestrian use of the side- } \\
\text { walks. }\end{array}$ \\
\hline $\begin{array}{l}\text { Land Use } \\
\text { Element }\end{array}$ & $\begin{array}{l}\text { LU 6-7 All revitalization, redevelopment and new } \\
\text { development projects in the Village Core shall include } \\
\text { appropriate site planning and urban design amenities } \\
\text { to encourage pedestrian travel. }\end{array}$ \\
\hline $\begin{array}{l}\text { Land Use } \\
\text { Element }\end{array}$ & $\begin{array}{l}\text { LU 6-8 Prohibit drive-through commercial structures } \\
\text { and other commercial uses dependent on direct auto- } \\
\text { motive access and disruptive to pedestrian orientation } \\
\text { in the Village Core. }\end{array}$ \\
\hline
\end{tabular}

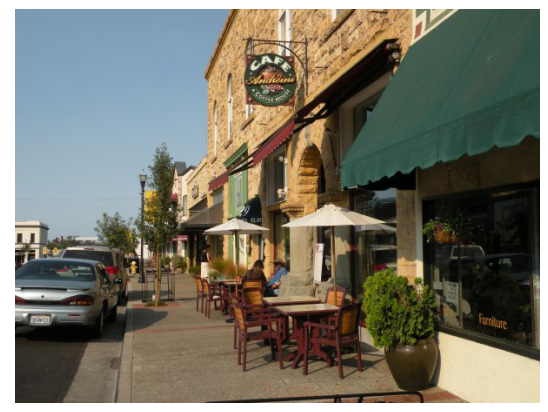

Outdoor dining contributes to an inviting pedestrian environment. (Image from www.winecoastcountry.com) 


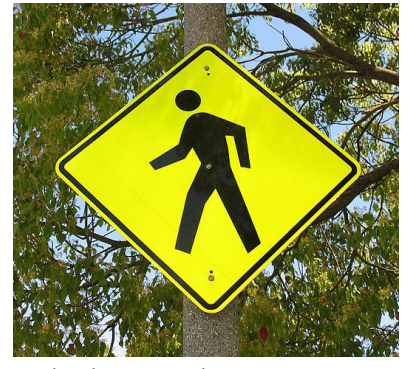

Vehicle trips that are replaced by walking trips result in reduced GHG emissions.

\begin{tabular}{|c|c|}
\hline $\begin{array}{l}\text { Land Use } \\
\text { Element }\end{array}$ & $\begin{array}{l}\text { LU6-9.1 Maintain a distinctive visual and physical } \\
\text { environment for the southern gateway streetscape in } \\
\text { accordance with the Design Guidelines for the Arroyo } \\
\text { Grande Village. These include the use of consistent } \\
\text { street trees, landscape (planters), street furniture } \\
\text { (benches, trash receptacles, news racks, etc.), street } \\
\text { and crosswalk paving, curb, sidewalk, and landscape } \\
\text { bulbouts, pedestrian-scaled lighting, identification } \\
\text { and directional signage, and other appropriate pedes- } \\
\text { trian scale elements. }\end{array}$ \\
\hline $\begin{array}{l}\text { Land Use } \\
\text { Element }\end{array}$ & $\begin{array}{l}\text { LU6-9.2 Link individual buildings with each other } \\
\text { through the use of walkways, in addition to sidewalks } \\
\text { and encourage shared or common parking. }\end{array}$ \\
\hline $\begin{array}{l}\text { Land Use } \\
\text { Element }\end{array}$ & $\begin{array}{l}\text { LU 7-8 Projects in Business Park areas shall be lo- } \\
\text { cated with direct access to arterial or non-residential } \\
\text { collector streets, and developed in a campus-like set- } \\
\text { ting with standards for landscaping, building façade } \\
\text { treatments, signage, pedestrian/employee amenities, } \\
\text { etc., Including but not limited to consideration of the } \\
\text { following: } \\
\text { a. arrange buildings around common pedestrian } \\
\text { walkways and public places (plazas, outdoor dining, } \\
\text { etc.) } \\
\text { b. development of pedestrian walkways, arcades, and/ } \\
\text { or other visual elements to interconnect individual } \\
\text { buildings; } \\
\text { c. use of common architectural design vocabulary } \\
\text { (materials, colors, design character, etc.) } \\
\text { d. use of extensive landscape in open areas and park- } \\
\text { ing lots, including broad landscaped setbacks from } \\
\text { principal peripheral streets; } \\
\text { e. location of parking to minimize views from princi- } \\
\text { pal peripheral streets; } \\
\text { f. enclosure of storage areas with decorative screening } \\
\text { or walls; } \\
\text { g. use of consistent and well-designed public and } \\
\text { informational signage; and } \\
\text { h. installation of elements defining the key entry } \\
\text { points and activity locations. }\end{array}$ \\
\hline $\begin{array}{l}\text { Land Use } \\
\text { Element }\end{array}$ & $\begin{array}{l}\text { LU12-7 Enhance pedestrian level activity within resi- } \\
\text { dential and commercial areas }\end{array}$ \\
\hline $\begin{array}{l}\text { Land Use } \\
\text { Element }\end{array}$ & $\begin{array}{l}\text { LU 12-7.6 Refine the Circulation Element to include } \\
\text { an integrated pedestrian circulation network link- } \\
\text { ing the Village Core and Mixed Use areas, schools, } \\
\text { shopping, community facilities, and multiple family } \\
\text { residential areas. (See also CT 3-3) }\end{array}$ \\
\hline
\end{tabular}


Bicycle, Pedestrian, and Transit Infrastructure

The following existing City policies provide improvements to infrastructure for alternative modes of transportation. This includes bike lanes and paths as well as bicycle parking, bus shelters, and park and ride lots. Such improvements make alternatives to driving more convenient options, thereby decreasing vehicle miles traveled.

Table 4: Bicycle, Pedestrian, and Transit Infrastructure

\begin{tabular}{|c|c|}
\hline Source & Title and Description \\
\hline $\begin{array}{l}\text { Land Use Ele- } \\
\text { ment }\end{array}$ & $\begin{array}{l}\text { LU7-5 A Specific Plan or property develop- } \\
\text { ment plan must be approved prior to any land } \\
\text { division or other development approval of } \\
\text { projects in the RC and BP areas. The Specific } \\
\text { Plan or property development shall stipulate } \\
\text { phasing of construction and responsibility for } \\
\text { public facility and infrastructure improve- } \\
\text { ments . RC and/or BP development plans shall } \\
\text { include Park and Ride lots, bike lockers, bus } \\
\text { shelters and/or similar alternative transporta- } \\
\text { tion facilities provided by the developer. }\end{array}$ \\
\hline $\begin{array}{l}\text { Circulation Ele- } \\
\text { ment }\end{array}$ & $\begin{array}{l}\text { CT3 Maintain and improve existing "multi- } \\
\text { modal" circulation and transportation systems } \\
\text { and facilities, to maximize alternatives to new } \\
\text { street and highway construction. }\end{array}$ \\
\hline $\begin{array}{l}\text { Circulation Ele- } \\
\text { ment }\end{array}$ & $\begin{array}{l}\text { CT3-3 Promote non-motorized bike and pe- } \\
\text { destrian circulation facilities to serve all areas } \\
\text { of the City and linking with regional system, } \\
\text { including neighborhood connections in addi- } \\
\text { tion to conventional streets. }\end{array}$ \\
\hline $\begin{array}{l}\text { Circulation Ele- } \\
\text { ment }\end{array}$ & $\begin{array}{l}\text { CT3-3.1 Improve bike lanes and sidewalks } \\
\text { serving all school, parks, and selected transit } \\
\text { and community facilities as a priority system, } \\
\text { including neighborhood connections in addi- } \\
\text { tion to conventional streets. }\end{array}$ \\
\hline $\begin{array}{l}\text { Circulation Ele- } \\
\text { ment }\end{array}$ & $\begin{array}{l}\text { CT3-3.2 Plan and prioritize Village Core and } \\
\text { E. Grand Avenue Mixed Use corridor im- } \\
\text { provements. }\end{array}$ \\
\hline $\begin{array}{l}\text { Circulation Ele- } \\
\text { ment }\end{array}$ & $\begin{array}{l}\text { CT3-3.3 Update City Bikeway Plan to meet } \\
\text { State guidelines to seek to increase regional } \\
\text { and state funding assistance. }\end{array}$ \\
\hline $\begin{array}{l}\text { Agriculture, } \\
\text { Conservation } \\
\text { and Open Space } \\
\text { Element }\end{array}$ & $\begin{array}{l}\text { C/OS3-1 In Residential Rural and Suburban } \\
\text { County areas and developments in the unin- } \\
\text { corporated portions of the planning, area, and } \\
\text { in all urban land use developments adjoining } \\
\text { possible trail alignments within the City, pro- } \\
\text { vide access to schools, parks and community } \\
\text { facility activity areas. }\end{array}$ \\
\hline
\end{tabular}

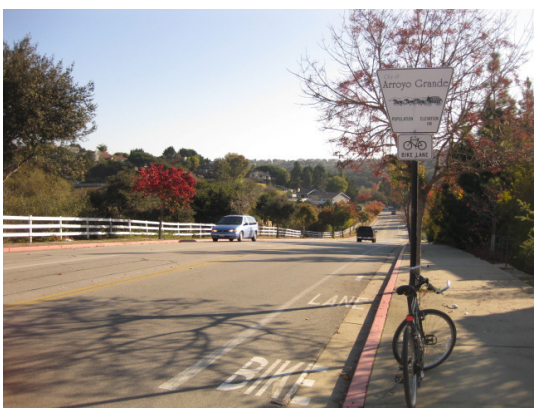

The Draft Bicycle and Trails Master Plan points out that most existing bicycle infrastructure consists of Class II bike lanes. 


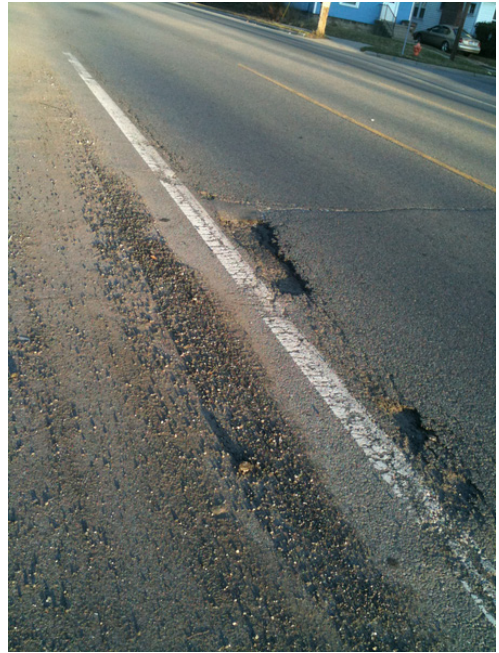

Arroyo Grande’s Bicycle Plan contains the policy to maintain a consistent sweeping schedule, which keeps debris off of bike routes and helps make bicycling safe and convenient.

\begin{tabular}{|c|c|}
\hline $\begin{array}{l}\text { Parks and Rec- } \\
\text { reation Element }\end{array}$ & $\begin{array}{l}\text { Implementation Measure PR2-2.5 Improve } \\
\text { bike lanes or paths that connect to County, } \\
\text { Pismo Beach, and Grover Beach systems and } \\
\text { serve priority parks and schools. }\end{array}$ \\
\hline $\begin{array}{l}\text { Parks and Rec- } \\
\text { reation Element }\end{array}$ & $\begin{array}{l}\text { Objective PR4 A network of recreational } \\
\text { trails, bicycle lanes and bikeways should be es- } \\
\text { tablished for use by local residents and visitors } \\
\text { to the Arroyo Grande Valley. }\end{array}$ \\
\hline Bicycle Plan & $\begin{array}{l}\text { OBJECTIVES Provide safe spaces for bicy- } \\
\text { cling through a comprehensive network of } \\
\text { bikeways that are appropriately signed and } \\
\text { marked. The facilities shall include on-street } \\
\text { routes, marked bicycle lanes, and off-street } \\
\text { paths and multi-purpose trails. } \\
\text { Ensure that the bikeway network: } \\
\text { 1. Provides access to all schools, recreation } \\
\text { facilities and transit stops } \\
\text { 2. Connects major residential and commercial } \\
\text { areas }\end{array}$ \\
\hline Bicycle Plan & $\begin{array}{l}\text { General Policies: } \\
\text { 3. The City's Department of Public Works } \\
\text { (DPW) will maintain a consistent sweeping } \\
\text { schedule, especially for bike routes adjoining } \\
\text { agricultural areas, which are susceptible to ac- } \\
\text { cumulating dirt and debris. }\end{array}$ \\
\hline Bicycle Plan & $\begin{array}{l}\text { General Policies: } \\
\text { 4. The City's Capital Improvement Program } \\
\text { (CIP) will increase the priority of the bikeway } \\
\text { network improvements within DPW street } \\
\text { repair and resurfacing schedules }\end{array}$ \\
\hline Bicycle Plan & $\begin{array}{l}\text { General Policies: } \\
\text { 5. The City will coordinate with SLOCOG, the } \\
\text { County and other agencies to promote inter- } \\
\text { modal connections between bikeways, transit, } \\
\text { park and ride lots and carpool locations. }\end{array}$ \\
\hline Bicycle Plan & $\begin{array}{l}\text { Class I Bikeways } \\
\text { 2. Class I Bikeways shall be located parallel } \\
\text { with Major highways, regional roads, rails, } \\
\text { and creeks where feasible to safely link impor- } \\
\text { tant destinations }\end{array}$ \\
\hline Bicycle Plan & $\begin{array}{l}\text { Class II Bikeways } \\
1 \text {. The ultimate intent is that all arterial and } \\
\text { collector streets shall include Class II bike- } \\
\text { ways. }\end{array}$ \\
\hline Bicycle Plan & $\begin{array}{l}\text { 3. BICYCLE PARKING } \\
\text { Provide convenient, secure, and nice-looking } \\
\text { short and long-term bicycle parking. }\end{array}$ \\
\hline
\end{tabular}




\begin{tabular}{|l|l|l|}
\hline Bicycle Plan & $\begin{array}{l}\text { Long-Term Parking } \\
\text { 1. Bicycle lockers, locked rooms, or standard } \\
\text { racks in a monitored location shall be provid- } \\
\text { ed to satisfy long-term bike parking, particu- } \\
\text { larly at major employment centers and public } \\
\text { facilities. }\end{array}$ & $\begin{array}{l}\text { LU5-9 All revitalization, redevelopment and } \\
\text { new development projects in Mixed Use cor- } \\
\text { ridors shall include appropriate site planning } \\
\text { and urban design amenities to encourage pe- } \\
\text { destrian travel and encourage bike and transit } \\
\text { access as well as automotive. }\end{array}$ \\
\hline $\begin{array}{l}\text { Land Use Ele- } \\
\text { ment }\end{array}$ & \\
\hline
\end{tabular}

\section{Implementation}

Arroyo Grande has made some improvements to bicycle infrastructure since the GHG Emissions Inventory base year (2005). Exact data as to the extent of improvements added since 2005 was not available, but these improvements are believed to include new bike lanes in the following locations:

- New portions on Grand Avenue

- Fair Oaks from South Elm to Valley Road

- Traffic Way from East Branch Street to East Cherry Avenue

- Orchard Road from Pilgrim Way to Castillo Del Mar

These additional bike lanes are estimated to total about 3 miles. Quantifying the GHG emissions reduction that resulted from these improvements is difficult because exact data on the current percentage of residents who commute by bicycle is not available, and the miles of bicycle lanes that existed prior to these improvements is uncertain. Additionally, most methods for quantifying emissions reductions resulting from increased bicycle lanes are designed for more densely populated areas.

\section{Potential for Future Emissions Reductions}

As reported in the Draft Bicycle and Trails Master Plan, "other" accounts for $4.45 \%$ of the modal split travel to work. $36 \%$ of commuters have a 15 minute or less travel time to work, which indicates that new infrastructure for bicycling has the potential to serve a large number of commuters. According to the CAPCOA Guidelines for quantifying emissions reductions strategies, a 2003 study (Dill and Carr) showed that adding one additional mile of bicycle lanes for each city square mile increases share of commuters commuting by bicycle by $1 \%$. Thus, adding bicycle infrastructure should be considered a good strategy for reducing emissions as well as providing the added benefits to health and air quality.

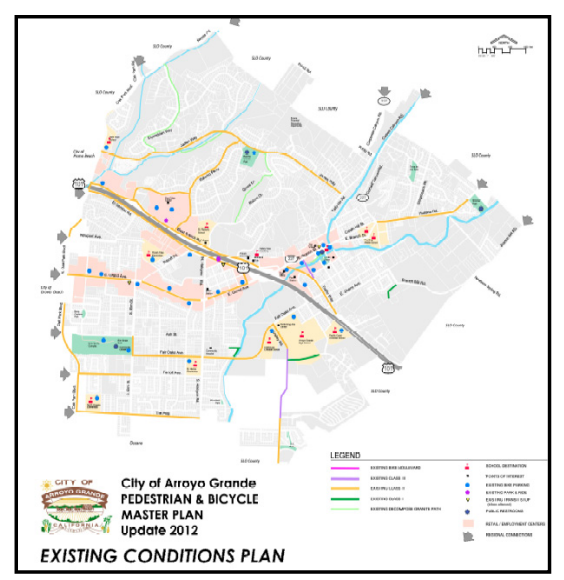

The Draft Bicycle and Trails Master Plan includes a map of existing bicycle routes, some of which were added after 2005. 


\section{Bicycle Education}

The following exiting City policies promote bicycling and educate the community on bicycle safety. Promotional activities can make bicycling safer and help people feel more confident in their knowledge and ability to ride a bicycle. This can decrease GHG emissions when people choose to ride a bicycle instead of driving a car.

Table 5: Bicycle Education

\begin{tabular}{|l|l|l|}
\hline Source & Title and Description & \\
\hline Bicycle Plan & $\begin{array}{l}\text { 4. BICYCLE SAFETY, EDUCATION, AND } \\
\text { OUTREACH Objective } \\
\text { Conduct annual or more frequent new and } \\
\text { existing education programs that promote } \\
\text { bicycle safety. }\end{array}$ & $\begin{array}{l}\text { 4. BICYCLE SAFETY, EDUCATION, AND } \\
\text { OUTREACH Policies } \\
\text { 1. Work with Regional Rideshare and San Luis } \\
\text { Obispo County Bicycle Coalition to encourage } \\
\text { promotional and educational activities within } \\
\text { the community. }\end{array}$ \\
\hline Bicycle Plan & $\begin{array}{l}\text { 4. BICYCLE SAFETY, EDUCATION, AND } \\
\text { OUTREACH Policies } \\
\text { 2. Work with Lucia Mar Unified School Dis- } \\
\text { trict to identify potential bicycle education } \\
\text { programs in schools. }\end{array}$ & \\
\hline
\end{tabular}

The SLO County Bicycle Coalition offers services and promotional activities to support bicycling in San Luis Obispo County.

\section{Public Transportation}

Use of public transportation as an alternative to trips made in personal vehicles can reduce GHG emissions. Busses can reduce per capita emissions because they can transport a large number of people at one time. Providing a convenient and reliable transit network and encouraging people to choose public transit over driving personal vehicles reduces the total number of personal vehicle trips and associated emissions.

\section{Expanding Transit Routes and Services}

Existing City Policies in Table 6 can help reduce GHG emissions by expanding transit routes, improving transit service to all groups, and making transit stops more comfortable for commuters. 


\begin{tabular}{|c|c|}
\hline Source & Title and Description \\
\hline $\begin{array}{l}\text { Land } \\
\text { Use Element }\end{array}$ & $\begin{array}{l}\text { LU6-9.3 Integrate improvements into the design } \\
\text { of individual sites and public streetscape that } \\
\text { facilitate transit access to the Village Core, such } \\
\text { as bus shelters and recessed turn-outs consistent } \\
\text { with historic character and particular location. }\end{array}$ \\
\hline $\begin{array}{l}\text { Circulation } \\
\text { Element }\end{array}$ & $\begin{array}{l}\text { CT4-1.1 Transit routes should serve E. Grand Av- } \\
\text { enue Mixed Use corridor, Village Core, and West } \\
\text { Branch street Regional Commercial Facility areas. }\end{array}$ \\
\hline $\begin{array}{l}\text { Circulation } \\
\text { Element }\end{array}$ & $\begin{array}{l}\text { CT4-1.2 Future transit loop to serve Halcyon/ } \\
\text { Fair Oaks, Offices, Village Core, James Way and } \\
\text { Rancho Parkway residential areas. }\end{array}$ \\
\hline $\begin{array}{l}\text { Circulation } \\
\text { Element }\end{array}$ & $\begin{array}{l}\text { CT3-1 In cooperation with SCAT and CCAT or } \\
\text { other operators, provide for safe and efficient } \\
\text { transit system for local and regional travel, partic- } \\
\text { ularly for youth, elderly, low-income or disabled } \\
\text { persons. }\end{array}$ \\
\hline $\begin{array}{l}\text { Circulation } \\
\text { Element }\end{array}$ & $\begin{array}{l}\text { CT3-1.1 The City should encourage convenient } \\
\text { routes and schedules on arterial and/or collec- } \\
\text { tor streets including stops, shelters, bus benches, } \\
\text { turnouts, park and ride, transfer and other facili- } \\
\text { ties or features to be provided in connection with } \\
\text { new developments. }\end{array}$ \\
\hline
\end{tabular}

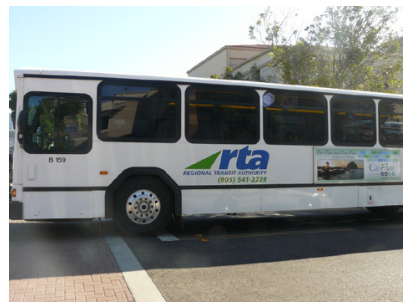

The Regional Transit Authority serves Arroyo Grande and neighboring regions.

\section{Employer Encouraged Alternative Transit Programs}

Encouraging employers to promote alternative modes of transportation can be a valuable strategy for GHG emissions reductions. Providing employees with incentives or alternatives to automobile travel can reduce personal vehicle trips and associated emissions. The following existing City policy encourages these programs.

Table 7: Employer Encouraged Alternative Transit Programs

\begin{tabular}{|c|c|}
\hline Source & Title and Description \\
\hline $\begin{array}{l}\text { Circulation } \\
\text { Element }\end{array}$ & $\begin{array}{l}\text { CT3-1.2 The City should encourage major em- } \\
\text { ployers to promote use of public transit and/or } \\
\text { provide van/car pools, private shuttles or other } \\
\text { trip reduction (flex time, telecommuting, bike) } \\
\text { and transportation demand management. }\end{array}$ \\
\hline
\end{tabular}

\section{Implementation}

Conversations with City staff indicated that few employer encouraged alternative transit programs are currently in place. 


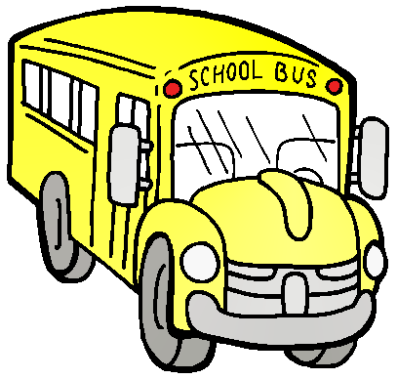

An adequate and well used school bus transportation system can minimize personal vehicle trips in getting children to school.

\section{School Bus Transportation System}

Emissions associated with transporting students to school can be reduced when an adequate school bus system replaces individual vehicle trips. The following policy aims to improve the school bus transportation system.

Table 8: School Bus System Improvements

\begin{tabular}{|l|l|l|}
\hline Source & Title and Description & \\
\hline Circulation & CT3-2 Cooperate with Lucia Mar Unified School \\
Element & $\begin{array}{l}\text { District to plan improved school bus transpor- } \\
\text { tation system, including parking and loading, } \\
\text { maintenance and storage, bike and sidewalk ac- } \\
\text { cess facilities. }\end{array}$ & \\
\hline
\end{tabular}




\section{Growth Management and Mixed-Use Policies}

Growth management can impact GHG emissions because the layout of a city greatly impacts how people choose to travel from one place to another. Compact development patterns typically lead to fewer vehicle trips than more spread out development patterns. Similarly, mixed-use development tends to encourage walking and bicycling because common destinations tend to be closer to one another.

\section{Affordable Housing and Transit Oriented Development}

Providing affordable housing in the City can potentially decrease commute distances for those working in Arroyo Grande who might commute from other cities. Additionally, locating higher density housing near transit corridors and commercial centers can improve accessibility for a large number of residents commuting by modes other than driving personal vehicles. Affordable housing types can include secondary dwelling units, mobile homes, multi-family housing units, and others. Table 9 lists existing City policies that can encourage affordable housing and transit oriented development.

Table 9: Affordable Housing and Transit Oriented Development

\begin{tabular}{|c|c|}
\hline Source & Title and Description \\
\hline $\begin{array}{l}\text { Land Use } \\
\text { Element }\end{array}$ & $\begin{array}{l}\text { LU2-5 In all Single Family Residential districts the } \\
\text { Development Code may allow accessory guest and/ } \\
\text { or secondary studio units as conditional uses. }\end{array}$ \\
\hline $\begin{array}{l}\text { Public Re- } \\
\text { view Draft } \\
\text { Housing } \\
\text { Element }\end{array}$ & $\begin{array}{l}\text { A.2-1. The City shall continue to encourage and } \\
\text { publicize on the City's website the secondary dwell- } \\
\text { ing program to increase public awareness. }\end{array}$ \\
\hline $\begin{array}{l}\text { Land Use } \\
\text { Element }\end{array}$ & $\begin{array}{l}\text { LU3-2.3 Encourage the location of mobile home } \\
\text { parks in areas having direct access to major transpor- } \\
\text { tation routes and in close proximity to Community } \\
\text { Facilities Mixed Use or Regional Commercial facili- } \\
\text { ties. }\end{array}$ \\
\hline $\begin{array}{l}\text { Land Use } \\
\text { Element }\end{array}$ & $\begin{array}{l}\text { LU3-4.2 Enable development of very high density } \\
\text { multi-family residential uses in locations with good } \\
\text { access to major transportation routes and in close } \\
\text { proximity to Community Facilities, Offices, Regional } \\
\text { Commercial and/or Mixed Use zones. }\end{array}$ \\
\hline
\end{tabular}

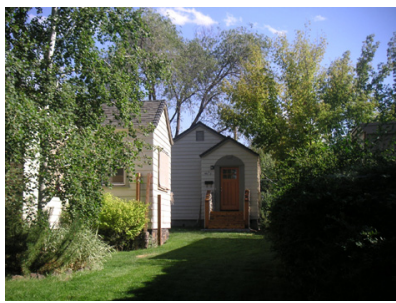

Accessory dwelling units add to the city's affordable housing supply. 


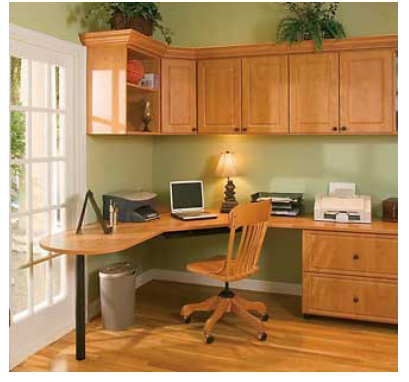

Home based businesses can reduce transportation emissions by eliminating the commute to work

\begin{tabular}{|c|c|}
\hline $\begin{array}{l}\text { Circula- } \\
\text { tion Ele- } \\
\text { ment }\end{array}$ & $\begin{array}{l}\text { CT4-1.3 Consider higher density allowance and re- } \\
\text { duced parking requirements within one-quarter mile } \\
\text { of transit routes when updating Development Code. }\end{array}$ \\
\hline $\begin{array}{l}\text { Public Re- } \\
\text { view Draft } \\
\text { Housing } \\
\text { Element }\end{array}$ & $\begin{array}{l}\text { A.2. The City shall continue to utilize the following } \\
\text { incentives for the production of affordable housing: } \\
\text { a) allowing secondary dwelling units under specified } \\
\text { criteria; b) allowing manufactured housing on legal } \\
\text { parcels in all residential zones; c) allowing density } \\
\text { bonuses for very low, low, and moderate-income } \\
\text { housing, and senior housing projects. }\end{array}$ \\
\hline $\begin{array}{l}\text { Public Re- } \\
\text { view Draft } \\
\text { Housing } \\
\text { Element }\end{array}$ & $\begin{array}{l}\text { A. } 4 \text { The City shall establish minimum residential } \\
\text { densities that are no lower than } 75 \text { percent of the } \\
\text { maximum densities allowed in each multi-family } \\
\text { residential zone, with exceptions made for properties } \\
\text { with significant environmental constraints. }\end{array}$ \\
\hline $\begin{array}{l}\text { Public Re- } \\
\text { view Draft } \\
\text { Housing } \\
\text { Element }\end{array}$ & $\begin{array}{l}\text { A.11. The City shall continue to utilize and expand } \\
\text { the Density Bonus program to encourage affordable } \\
\text { housing supply. }\end{array}$ \\
\hline $\begin{array}{l}\text { Public Re- } \\
\text { view Draft } \\
\text { Housing } \\
\text { Element }\end{array}$ & $\begin{array}{l}\text { A.10-1. To facilitate affordable housing, the City } \\
\text { shall comply with State Density Bonus Law. The } \\
\text { City shall update Development Code Chapter } 16.82 \\
\text { to comply with AB } 2280 \text {. The City will continue to } \\
\text { update Chapter } 16.82 \text { on an ongoing basis to comply } \\
\text { with any future updates to State Density Bonus law } \\
\text { (Government Code Section 65915) as well as evalu- } \\
\text { ate proposed Development Code amendments to as- } \\
\text { sess whether they pose any constraints to developer } \\
\text { utilization of density bonuses. }\end{array}$ \\
\hline $\begin{array}{l}\text { Circula- } \\
\text { tion Ele- } \\
\text { ment }\end{array}$ & $\begin{array}{l}\text { CT4-1 Promote "transit-oriented developments" and } \\
\text { coordinated, compatible land use pattern by encour- } \\
\text { aging multiple family residential and special needs } \\
\text { housing in Mixed Use Corridors, Village Core and } \\
\text { near Office, Regional Commercial, Business Park, } \\
\text { and major Community Facility areas. }\end{array}$ \\
\hline
\end{tabular}

\section{Home-Based Occupations}

Home-based businesses allow residents to work and live in one place, eliminating or minimizing work-related travel. This reduces vehicle miles traveled and congestion during peak commute times, and subsequently can result in decreased emissions from vehicle travel. (See table 10.)

Table 10: Home-Based Occupations

\begin{tabular}{|l|l|l|}
\hline Source & Title and Description & \\
\hline $\begin{array}{l}\text { Land Use } \\
\text { Element }\end{array}$ & $\begin{array}{l}\text { LU2-6 Permit compatible home-based businesses } \\
\text { (home occupations) in all residential areas, subject } \\
\text { to applicable economic development element poli- } \\
\text { cies and City of Arroyo Grande Development Code } \\
\text { and other regulations. }\end{array}$ & \\
\hline
\end{tabular}




\section{Mixed-Use Development}

Mixed-Use developments allow residences, commercial properties, and community facilities to exist in closer proximity to one another. This makes transit use, bicycling, and walking convenient transportation choices to accomplish many daily needs and activities. Pairing mixed-use development with alternative transportation infrastructure can further increase travel by these modes. The following existing City policies can help reduce vehicle miles traveled by encouraging mixed-use development.

\section{Table 11: Mixed-Use Development}

\begin{tabular}{|c|c|}
\hline Source & Title and Description \\
\hline $\begin{array}{l}\text { Land Use } \\
\text { Element }\end{array}$ & $\begin{array}{l}\text { LU5-1 Provide for a diversity of retail and service } \\
\text { commercial, offices, residential and other compatible } \\
\text { uses that support multiple neighborhoods and the } \\
\text { greater community, and reduce the need for external } \\
\text { trips to adjacent jurisdictions, by designating Mixed } \\
\text { Use areas along and near major arterial streets and at } \\
\text { convenient, strategic locations in the community. }\end{array}$ \\
\hline $\begin{array}{l}\text { Land Use } \\
\text { Element }\end{array}$ & $\begin{array}{l}\text { LU5-3 Ensure that all projects developed in the MU } \\
\text { areas include appropriate site planning and urban } \\
\text { design amenities to encourage travel by walking, } \\
\text { bicycling and public transit. }\end{array}$ \\
\hline $\begin{array}{l}\text { Land Use } \\
\text { Element }\end{array}$ & $\begin{array}{l}\text { LU5-8 Provide for different combinations, configura- } \\
\text { tions and mixtures of commercial, office and resi- } \\
\text { dential uses designating the East Grand Avenue, El } \\
\text { Camino Real and Traffic Way corridors as Mixed Use } \\
\text { (MU). }\end{array}$ \\
\hline $\begin{array}{l}\text { Land Use } \\
\text { Element }\end{array}$ & $\begin{array}{l}\text { LU5-9 All revitalization, redevelopment and new } \\
\text { development projects in Mixed Use corridors shall } \\
\text { include appropriate site planning and urban design } \\
\text { amenities to encourage pedestrian travel and en- } \\
\text { courage bike and transit access as well as automotive. }\end{array}$ \\
\hline $\begin{array}{l}\text { Land Use } \\
\text { Element }\end{array}$ & $\begin{array}{l}\text { LU5-11 Promote a mixture of residential and com- } \\
\text { mercial uses along Mixed Use corridors including } \\
\text { substantial landscaping and streetscape improve- } \\
\text { ments. }\end{array}$ \\
\hline $\begin{array}{l}\text { Land Use } \\
\text { Element }\end{array}$ & $\begin{array}{l}\text { LU5-11.4 Promote public transit-oriented develop- } \\
\text { ment by allowing density bonuses and Mixed Uses } \\
\text { with shared or public parking reduction to conven- } \\
\text { tional individual parking requirements. }\end{array}$ \\
\hline $\begin{array}{l}\text { Land Use } \\
\text { Element }\end{array}$ & $\begin{array}{l}\text { LU6-4 Ground floor residential uses shall be condi- } \\
\text { tionally permitted. Upstairs apartments are encour- } \\
\text { aged in conjunction with ground floor commercial } \\
\text { uses. }\end{array}$ \\
\hline
\end{tabular}

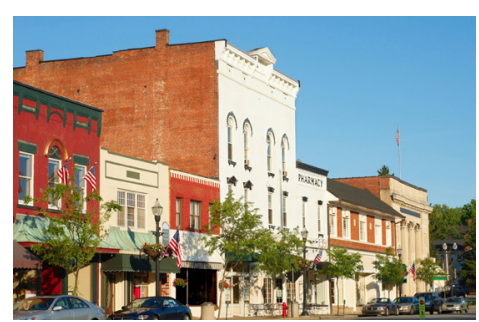

Walking and bicycling is a convenient way to get around in most mixed-use developments 


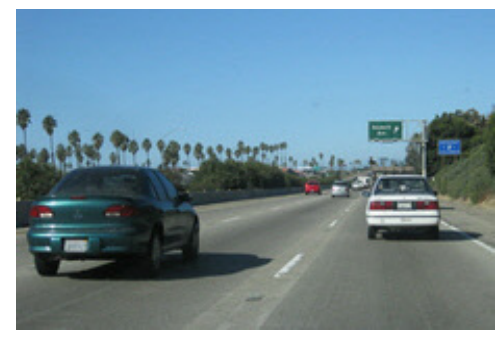

Minimizing non-local traffic on local roads can help limit congestion and decrease emissions.

\begin{tabular}{|l|l|l|}
\hline $\begin{array}{l}\text { Public Re- } \\
\text { view Draft } \\
\text { Housing } \\
\text { Element }\end{array}$ & $\begin{array}{l}\text { A.5. The City shall encourage housing compat- } \\
\text { ible with commercial and office uses and promote } \\
\text { "mixed use" and "village core" zoning districts to } \\
\text { facilitate residential uses to be integrated into such } \\
\text { areas. }\end{array}$ & $\begin{array}{l}\text { Land Use } \\
\text { Element } \\
\text { parks and recreation areas may also be conditionally } \\
\text { permitted in any other land use designation based } \\
\text { the cite and environs. Schools, parks and recreations } \\
\text { facilities may be conditionally permitted in or ad- } \\
\text { joining residential neighborhoods or mixed use areas } \\
\text { where the facilities are intended to serve the areas in } \\
\text { which they are located. }\end{array}$ \\
\hline $\begin{array}{l}\text { Public Re- } \\
\text { view Draft }\end{array}$ & $\begin{array}{l}\text { A.1-3. The City shall amend the Development } \\
\text { Code to revise the requirements for the Traffic Way } \\
\text { Element }\end{array}$ & $\begin{array}{l}\text { Mixed Use District to remove the limitation to only } \\
\text { live-work residential uses. A mix of residential use } \\
\text { types shall be allowed as allowed in all of the mixed } \\
\text { use zoning districts (except the Industrial Mixed } \\
\text { Use District). The Development Code shall also be } \\
\text { amended to allow residential projects at densities } \\
\text { up to 20 units per acre in the Traffic Way Mixed Use } \\
\text { District. }\end{array}$ \\
\hline
\end{tabular}

\section{Limiting Through Traffic on Local Roads}

The following policies can help limit traffic on local roads, thereby decreasing GHG emissions from non-local traffic passing through the City.

Table 12: Limiting Through Traffic on Local Roads

\begin{tabular}{|l|l|l|}
\hline Source & Title and Description & \\
\hline $\begin{array}{l}\text { Land Use Ele- } \\
\text { ment }\end{array}$ & $\begin{array}{l}\text { LU7-1 Designate Regional Commercial (RC) } \\
\text { or Business Park (BP) uses in proximity to } \\
\text { the US-101 freeway, where adequate access } \\
\text { is provided to/from the freeway system and } \\
\text { adjacent arterial roads. }\end{array}$ & $\begin{array}{l}\text { LU12-6.1 Incorporate provisions into the } \\
\text { Development Code which would discourage } \\
\text { non-local through traffic on local streets, and } \\
\text { require maintenance of two points of access } \\
\text { to all residential neighborhoods. }\end{array}$ \\
\hline $\begin{array}{l}\text { Land Use Ele- } \\
\text { ment }\end{array}$ & \\
\hline
\end{tabular}




\section{Cluster Development}

Clustering development can help reduce GHG emissions in multiple ways. Minimizing sprawl can reduce vehicle miles traveled as well as the energy associated with pumping water long distances. Additionally, clustering development can preserve open space and vegetation, which sequesters carbon and thus lowers total community-wide emissions. (See Table 13.)

Table 13: Cluster development

\begin{tabular}{|l|l|l|}
\hline Source & Title and Description & \\
\hline $\begin{array}{l}\text { Land Use } \\
\text { Element }\end{array}$ & $\begin{array}{l}\text { LU10-2.3 Encourage appropriate use of Specific } \\
\text { Plans, and/or Planned Development combining } \\
\text { designation with beneficial features that could } \\
\text { not otherwise be achieved. Examples of such } \\
\text { features include clustering houses and maintain- } \\
\text { ing open spaces, mixed use, and a design that is } \\
\text { sensitive to the site as a whole and its setting. }\end{array}$ & $\begin{array}{l}\text { LU12-2.8 Design small lot single family and mul- } \\
\text { tiple family residential projects in such a man- } \\
\text { ner as to group dwellings around common open } \\
\text { space and/or recreational features. }\end{array}$ \\
\hline $\begin{array}{l}\text { Land Use } \\
\text { Element }\end{array}$ & $\begin{array}{l}\text { Ag2 Allocate and conserve ground and surface } \\
\text { water resources for agricultural use and minimize } \\
\text { potential Fringe Area and urban development } \\
\text { that would divert such resources from agricul- } \\
\text { ture. }\end{array}$ & $\begin{array}{l}\text { Conservation } \\
\text { and Open } \\
\text { Space Ele- } \\
\text { ment }\end{array}$ \\
\hline $\begin{array}{l}\text { Agriculture, } \\
\text { Conservation } \\
\text { and Open } \\
\text { Space Ele- } \\
\text { ment }\end{array}$ & $\begin{array}{l}\text { Ag/C/OS.10 Encourage the use of cluster land } \\
\text { divisions and cluster development that will locate } \\
\text { development on the least environmentally sensi- } \\
\text { tive portions of properties where the balance of } \\
\text { land is preserved in Permanent Open Space. }\end{array}$ & \\
\hline
\end{tabular}

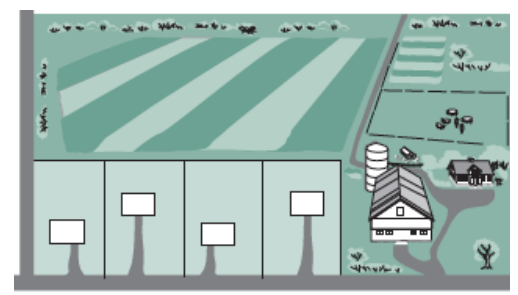

Clustering houses can preserve open space. 


\section{Buildings Policies}

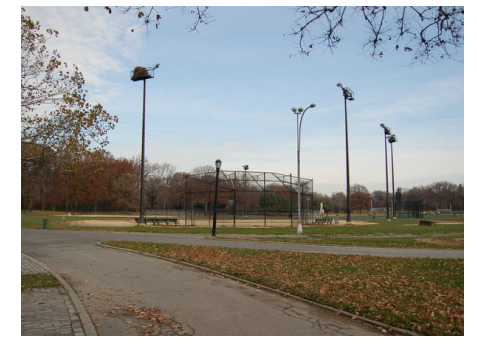

Arroyo Grande is considering converting the lights on the city's ballfield to a green system. According to city staff, this would result in an efficiency increase of 33 percent over the current system, which uses metal halide lights. A Green system uses lower wattage lamps with a reflective casing to achieve more lighting with less energy usage.
The built environment accounts for $37 \%$ of total community-wide emissions in Arroyo Grande. This includes emissions from both the residential and the commercial/industrial sector. The use of electricity and natural gas in heating, cooling, lighting, ventilation, and appliances account for the majority of building emissions. Policies that encourage green building design and energy efficiency help to reduce GHG emissions from the built environment.

\section{Green Building Design}

The following existing City policies can reduce energy consumption and the associated GHG emissions by maximizing natural climate control potential and incorporating vegetation, which can both sequester carbon and provide shade.

Table 14: Green Building Design

\begin{tabular}{|l|l|}
\hline Source & Description \\
\hline Land Use Element & $\begin{array}{l}\text { LU12-11.6 Shadow patterns created by } \\
\text { architectural elements such as overhangs, } \\
\text { projections, or recession of stories, balco- } \\
\text { nies, reveals, and awnings are encouraged in } \\
\text { order to contribute to a building's character } \\
\text { and aid in climate control. }\end{array}$ \\
\hline $\begin{array}{l}\text { Public Review Draft } \\
\text { Housing Element }\end{array}$ & $\begin{array}{l}\text { M.3. When feasible, buildings shall be sited } \\
\text { on a north-south axis and designed to take } \\
\text { advantage of passive solar heating and cool- } \\
\text { ing. }\end{array}$ \\
\hline Land Use Element & $\begin{array}{l}\text { LU 12-8 Emphasize the incorporation of } \\
\text { landscape themes and extensive landscaped } \\
\text { areas into new development; provide land- } \\
\text { scaping and open spaces as an integral } \\
\text { part of project design to enhance building } \\
\text { design, public views, and interior spaces; } \\
\text { provide buffers and transitions as needed; } \\
\text { and facilitate energy conservation. }\end{array}$ \\
\hline
\end{tabular}


Energy efficient buildings use less electricity and natural gas. The following existing City policies aim to improve energy efficiency in existing residential units, and encourage energy efficiency in new residential projects. (See Table 15.)

Table 15: Energy Efficiency

\begin{tabular}{|l|l|l|}
\hline Source & Title and Description & \\
\hline $\begin{array}{l}\text { Public Review Draft } \\
\text { Housing Element }\end{array}$ & $\begin{array}{l}\text { M.1-1. The City shall continue work- } \\
\text { ing to implement a water and electrical } \\
\text { retrofit program for existing housing } \\
\text { units. A plumbing retrofit program was } \\
\text { established in 2004, and water conserva- } \\
\text { tion rebate programs were established } \\
\text { in 2009. The City will continue to work } \\
\text { with PG\&E and other agencies to estab- } \\
\text { lish an electrical retrofit program. }\end{array}$ & $\begin{array}{l}\text { M.1-2. The City shall establish a program } \\
\text { to allow residential projects to receive } \\
\text { minor exceptions if they meet 25\% of } \\
\text { items on the Tier 1 list of the California } \\
\text { Green Building Code (Title 24) or 15\% } \\
\text { of items on the Tier 2 list of that code. }\end{array}$ \\
\hline Public Review Draft Element & \\
\hline
\end{tabular}

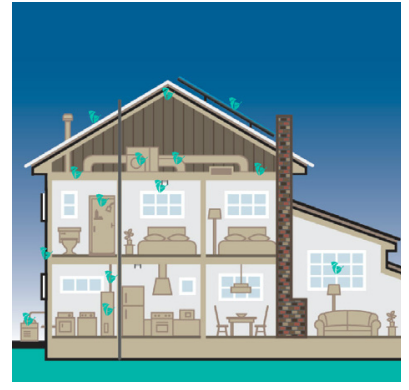

Improving energy efficiency in residential buildings can reduce emissions associated with energy consumption. (photo from Energy Upgrade California website)

\section{Implementation}

Conversations with City staff indicated that electrical retrofit programs for existing residential construction are not currently in place, although some rebate and incentive programs are available through the utility companies. 


\section{Energy Efficiency in Municipal Buildings}

\section{Municipal Building Retrofits}

In 2010 and 2011, Arroyo Grande made several changes to municipal buildings, which have improved energy efficiency and subsequently reduced GHG emissions. Table 16 lists measures taken and estimations of resulting emissions reductions.

Table 16: Energy Efficiency in Municipal Buildings and Quantifications

\begin{tabular}{|l|l|l|l|l|l|}
\hline Measures Taken & Locations & $\begin{array}{l}\text { Savings esti- } \\
\text { mate }\end{array}$ & CO2lbs & CH4lbs & N2O \\
\hline $\begin{array}{l}\text { HVAC Replace- } \\
\text { ment Projects }\end{array}$ & $\begin{array}{l}\text { Community Center, } \\
\text { Corporate yard, City } \\
\text { Council Chambers, } \\
\text { Farm Credit Bureau, } \\
\text { Parks and Recreation, } \\
\text { Soto Sports Complex }\end{array}$ & $\begin{array}{l}12740 \mathrm{kWh} \\
351 \mathrm{Therm}\end{array}$ & $\begin{array}{l}80170.7^{\star} \\
283.73^{\star * *}\end{array}$ & $0.37^{\star}$ & $0.14^{\star}$ \\
\hline Lighting retrofits & $\begin{array}{l}\text { City Hall, Community } \\
\text { Center, Corporate Yard, } \\
\text { City Council Chambers, } \\
\text { Farm Credit Bureau, } \\
\text { Fire Station, Parks and } \\
\text { Recreation, Soto Sports } \\
\text { Complex }\end{array}$ & & $13118.7^{\star}$ & $.59^{\star}$ & $.23^{\star}$ \\
\hline
\end{tabular}

\section{Occupancy Sensors}

As an additional energy savings measure, approximately 12 occupancy sensors were installed in various locations. Energy savings data was not available for this measure.

${ }^{*} k$ Wh equivalencies based on California Emissions Estimator Model rates based on location and utility provider.

**Source: Arroyo Grande Loan Report, obtained from PG\&E

${ }^{* * *}$ Therm CO2 equivalency based on EPA formula at: http://www.epa. gov/cleanenergy/energy-resources/calculator.html 


\section{Water Policies}

Electricity use associated with water delivery and treatment contributes to GHG emissions. Policies that reduce water consumption or improve the energy efficiency of the water pumping process can reduce associated emissions. Since 2005, Arroyo Grande has implemented multiple policies and programs that reduce GHG emissions associated with water use.

\section{Water Conservation}

Arroyo Grande adopted a Water Conservation ordinance in 2003. The following existing City policies help reduce water usage and subsequently the energy used to pump and treat water.

Table 17: Water Conservation

\begin{tabular}{|l|l|l|}
\hline Municipal Code & $\begin{array}{l}\text { Water conservation requirements: Estab- } \\
\text { lished requirements effective at all times: } \\
\text { A. Use of water which results in excessive } \\
\text { gutter runoff is prohibited. }\end{array}$ & \\
\hline Municipal Code & $\begin{array}{l}\text { B. Outdoor Water Use - Except Irrigation. } \\
\text { 13.05.030 B }\end{array}$ & $\begin{array}{l}\text { 1. No water shall be used for cleaning drive- } \\
\text { ways, patios, parking lots, sidewalks, streets } \\
\text { or other such use except where necessary to } \\
\text { protect the public health and safety; } \\
\text { 2. Outdoor water use for washing vehicles } \\
\text { shall be attended and have hand-controlled } \\
\text { watering devices. }\end{array}$ \\
\hline Municipal Code & $\begin{array}{l}\text { C. Outdoor Irrigation. } \\
\text { 13.05.030 C } \\
\text { 1. Outdoor irrigation is prohibited between } \\
\text { the hours of ten a.m. and four p.m. } \\
\text { 2. Irrigation of private and public landscap- } \\
\text { ing, turf areas and gardens is permitted at } \\
\text { even-numbered addresses only on Mondays } \\
\text { and Thursdays and at odd-numbered ad- } \\
\text { dresses only on Tuesdays and Fridays. No } \\
\text { irrigation of private and public landscap- } \\
\text { ing, turf areas and gardens is permitted on } \\
\text { Wednesdays. Irrigation is permitted at all } \\
\text { addresses on Saturdays and Sundays how- } \\
\text { ever, in all cases customers are directed to } \\
\text { use no more water than necessary to main- } \\
\text { tain landscaping. }\end{array}$ \\
\hline
\end{tabular} \mid

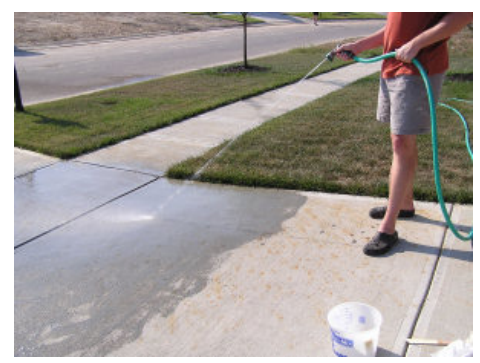

Using water to clean driveways and sidewalks is prohibited in Arroyo Grande.

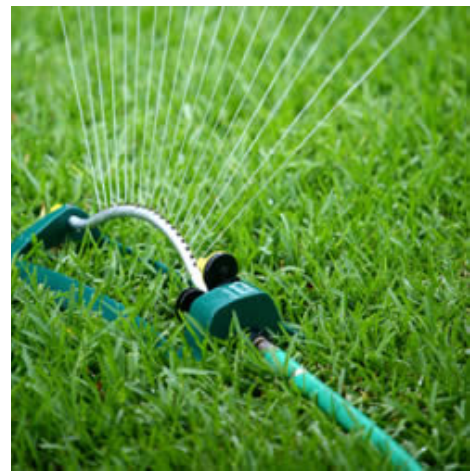

Limiting outdoor irrigation during the hottest part of the day minimizes water lost to evaporation. 


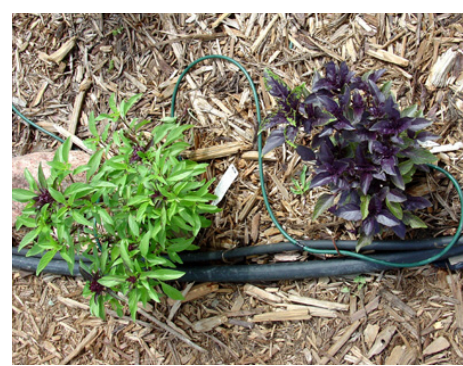

Drip irrigation is recommended for non-turf areas.

\begin{tabular}{|l|l|l|}
\hline Municipal Code & $\begin{array}{l}\text { D. Emptying and refilling swimming pools } \\
\text { and commercial spas is prohibited except to } \\
\text { prevent structural damage and/or to pro- } \\
\text { vide for the public health and safety. }\end{array}$ & \\
\hline $\begin{array}{l}\text { Municipal Code } \\
\text { 13.05.030 E }\end{array}$ & $\begin{array}{l}\text { E. Use of potable water for soil compaction } \\
\text { or dust control purposes in construction } \\
\text { activities is prohibited unless specifically } \\
\text { approved by the city. }\end{array}$ & \\
\hline $\begin{array}{l}\text { Municipal Code } \\
\text { 13.06.020 }\end{array}$ & $\begin{array}{l}\text { Retrofit upon sale. } \\
\text { Requires compliance with the retrofit } \\
\text { requirements of this chapter by obtaining a } \\
\text { water conservation certificate. }\end{array}$ & \\
\hline
\end{tabular}

\section{Water Efficient Landscaping}

An estimated $60 \%$ of the city's water is used for irrigation (Cash for Grass Program Application). The following existing City polices help limit the use of water in landscaping and thus reduce associated energy use to pump and treat the water.

Table 18: Water Efficient Landscaping

\begin{tabular}{|c|c|}
\hline Source / Title & Description \\
\hline $\begin{array}{l}\text { Municipal Code } \\
16.84 .040 \mathrm{~A}\end{array}$ & $\begin{array}{l}\text { Turf limitations for new construction and } \\
\text { rehabilitated landscapes } \\
\text { All new construction projects (residential, } \\
\text { commercial, industrial) shall comply with the } \\
\text { following limitations: } \\
\text { 1. Turf areas less than eight feet in width in } \\
\text { any direction are prohibited, unless subsur- } \\
\text { face irrigation is used and maximum turf } \\
\text { areas do not exceed the percentages outlined } \\
\text { in this chapter. } \\
\text { 2. Turf shall be prohibited within the public } \\
\text { right-of-way, including parkways. } \\
\text { 3. Development shall be graded to maximize } \\
\text { the on-site distribution of runoff to planted } \\
\text { areas. } \\
\text { 4. For non-turf areas, drip irrigation methods } \\
\text { and low water use plants are recommended. } \\
\text { 5. Covenants, conditions and restrictions } \\
\text { (CC\&Rs) shall not require turf landscaping } \\
\text { nor have the effect of prohibiting low-water } \\
\text { use landscaping and shall include by reference } \\
\text { and/or attachment a copy of Chapter } 16.84\end{array}$ \\
\hline
\end{tabular}




\begin{tabular}{|c|c|}
\hline $\begin{array}{l}\text { Municipal Code } \\
16.84 .040 \text { B }\end{array}$ & $\begin{array}{l}\text { Commercial and Industrial Projects: } \\
\text { 1. The area planted in turf grass and irrigated } \\
\text { with spray irrigation shall be limited to ten } \\
\text { (10) percent of the development's landscaped } \\
\text { area. } \\
\text { 2. Exceptions: This section does not apply to } \\
\text { cemeteries, plant collections as part of bo- } \\
\text { tanical gardens and arboretums open to the } \\
\text { public, city parks, and school sports fields. }\end{array}$ \\
\hline $\begin{array}{l}\text { Municipal Code } \\
\text { 16.84.040 C }\end{array}$ & $\begin{array}{l}\text { Single Family Residences: } \\
\text { 1. Turf grass installed with spray irrigation } \\
\text { in residential front yards shall be limited to } \\
\text { twenty-five (25) percent of the landscaped } \\
\text { area. } \\
\text { 2. The common areas in residential subdivi- } \\
\text { sions planted in turf (including landscape and } \\
\text { lighting district areas) shall be limited to ten } \\
\text { (10) percent of the landscaped area (exclud- } \\
\text { ing active play areas such as ball fields, play- } \\
\text { grounds, and picnic areas). }\end{array}$ \\
\hline $\begin{array}{l}\text { Municipal Code } \\
\text { 16.84.040 D }\end{array}$ & $\begin{array}{l}\text { Model Homes: } \\
\text { 1. Turf grass shall be prohibited in the front } \\
\text { yards of model homes, and shall be limited to } \\
\text { fifty (50) percent for the landscaped area in } \\
\text { back and side yards. } \\
\text { 2. Model homes shall be used to educate } \\
\text { future home owners about water efficient } \\
\text { landscape and irrigation techniques. Educa- } \\
\text { tion features for model homes shall include: } \\
\text { (a) The installation of interpretive landscape } \\
\text { information signs that describe the prin- } \\
\text { ciples of water efficient landscapes includ- } \\
\text { ing features such as hydrozones, appropriate } \\
\text { irrigation equipment and other techniques } \\
\text { that contribute to the overall water efficient } \\
\text { irrigation theme. } \\
\text { (b) Information shall be provided to new } \\
\text { home owners that include techniques on de- } \\
\text { signing, installing, managing and maintaining } \\
\text { water efficient landscapes. }\end{array}$ \\
\hline $\begin{array}{l}\text { Municipal Code } \\
16.84 .040 \mathrm{E}\end{array}$ & $\begin{array}{l}\text { Multi-family Residential Projects: } \\
\text { 1. Turf grass shall be limited to twenty (20) } \\
\text { percent of the total landscaped area. The } \\
\text { twenty (20) percent limitation shall be exclu- } \\
\text { sive of areas designed as active play surfaces } \\
\text { (e.g. ball fields, playgrounds, picnic areas). } \\
\text { F. Rehabilitated Landscapes: } \\
\text { 1. Rehabilitated landscapes shall comply with } \\
\text { the turf limitations outlined in Sections A-E } \\
\text { above, as appropriate to the property type. }\end{array}$ \\
\hline
\end{tabular}

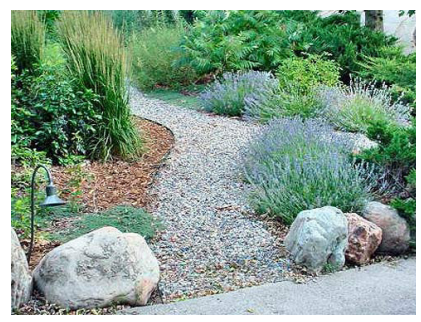

Water efficient landscaping reduces water use. 


\begin{tabular}{|c|c|}
\hline $\begin{array}{l}\text { Munici- } \\
\text { pal Code } \\
16.84 .050 \\
\text { A }\end{array}$ & $\begin{array}{l}\text { Landscape and irrigation system design and information require- } \\
\text { ments. } \\
\text { All project landscaping and irrigation plans/designs shall comply } \\
\text { with the following standards: } \\
\text { 1.Rain sensors, either integral or auxiliary, that suspend irrigation } \\
\text { during and after rainfall events, shall be required on all irrigation } \\
\text { control systems. } \\
\text { 2. Prohibit turf on slopes greater than twenty (20) percent where } \\
\text { the toe of the slope is adjacent to an impermeable hardscape } \\
\text { (where twenty (20) percent means one foot of vertical elevation } \\
\text { change for every five feet of horizontal length rise divided by run } \\
\text { times one hundred (100)). } \\
\text { 3. Water features shall use recirculating water systems. } \\
\text { 4. Prohibit overhead spray irrigation within twenty-four (24) } \\
\text { inches of non-permeable surfaces such as, but not limited to, } \\
\text { concrete sidewalks and driveways. Subsurface irrigation may } \\
\text { be used as long as other requirements of this chapter are met. } \\
\text { Allowable irrigation within the setback from non-permeable } \\
\text { surfaces may include drip, drip line, or other low-flow non-spray } \\
\text { type of systems. The setback area may be planted or non-planted. } \\
\text { The surfacing of the setback may be mulch, gravel, cobles, or } \\
\text { other porous material. These restrictions may be modified if the } \\
\text { landscape area is adjacent to permeable surfacing, and no runoff } \\
\text { occurs or the adjacent non-permeable surface drains entirely to } \\
\text { landscaped areas. } \\
\text { 5. Irrigation systems shall be designed and constructed to achieve } \\
\text { a minimum efficiency of seventy-one ( } 71 \text { ) percent. } \\
\text { 6. Apply minimum two inch layer of mulch on all exposed soil } \\
\text { surface of planting areas. } \\
\text { 7. The architectural guidelines and covenants, conditions, and } \\
\text { restrictions of common interest developments shall not have the } \\
\text { effect of prohibiting the use of low-water use plants or requiring } \\
\text { turf grass in landscaped areas. }\end{array}$ \\
\hline $\begin{array}{l}\text { Munici- } \\
\text { pal Code } \\
\text { Chap- } \\
\text { ter } 16 \\
16.84 .050 \\
\text { B }\end{array}$ & $\begin{array}{l}\text { Projects that have a landscape area equal to or greater than one } \\
\text { acre shall submit the following information: } \\
\text { 1. All of the items identified in Section A above. } \\
\text { 2. Weather-based irrigation controllers, soil moisture-based } \\
\text { controllers, or other self-adjusting irrigation controllers shall be } \\
\text { required for irrigation scheduling. } \\
\text { 3. The following documents and plans shall be submitted prior to } \\
\text { the issuance of a building permit for the associated project (refer } \\
\text { to the Landscape \& Irrigation Design Guide for specific forms } \\
\text { and criteria): } \\
\text { - Project Information } \\
\text { - Water Efficient Landscape Worksheet } \\
\text { - Soil Management Report } \\
\text { - Landscape Design Plan } \\
\text { - Irrigation Design Plan } \\
\text { - Grading Design Plan } \\
\text { 4. The following documents and plans shall be completed and } \\
\text { the landscape and irrigation project shall be installed prior to the } \\
\text { issuance of a certificate of occupancy for the associated project } \\
\text { (refer to the Landscape \& Irrigation Design Guide for specific } \\
\text { forms and criteria): } \\
\text { - Irrigation Scheduling } \\
\text { - Landscape and Irrigation Maintenance Schedule } \\
\text { - Irrigation Audit, Irrigation Survey and Irrigation Water Use } \\
\text { Analysis } \\
\text { - Irrigation Efficiency } \\
\text { - Stormwater Management }\end{array}$ \\
\hline
\end{tabular}


Water Conservation Programs

Arroyo Grande has implemented several programs to conserve water. These programs are established in the Urban Water Management Plan. (See Table 19). The programs help residents use less water, which results in less energy used in pumping and treating water.

Table 19: Water Conservation programs

\begin{tabular}{|c|c|}
\hline $\begin{array}{l}\text { Urban Water } \\
\text { Management Plan } \\
\text { Chapter } 6\end{array}$ & $\begin{array}{l}\text { Cash for Grass Rebate Program } \\
\text { The City's Cash for Grass Program helps } \\
\text { property owners convert water-thirsty } \\
\text { grass to a water efficient landscape. Cus- } \\
\text { tomers can receive rebates for } \$ 0.50 / \text { square } \\
\text { foot for a minimum } \$ 125 \text { or } 250 \text { square } \\
\text { feet removed and a maximum } \$ 2500 \text { or } \\
5,000 \text { square feet or more of grass removed. }\end{array}$ \\
\hline $\begin{array}{l}\text { Urban Water } \\
\text { Management Plan } \\
\text { Chapter } 6.2\end{array}$ & Residential Plumbing Retrofit Program \\
\hline $\begin{array}{l}\text { Urban Water } \\
\text { Management Plan } \\
\text { Chapter } 6\end{array}$ & $\begin{array}{l}\text { Smart Irrigation Program Controllers and } \\
\text { Sensors Program } \\
\text { The City surveys and completes an irriga- } \\
\text { tion audit report for each customer who } \\
\text { requests a smart irrigation controller. }\end{array}$ \\
\hline $\begin{array}{l}\text { Urban Water } \\
\text { Management Plan } \\
\text { Chapter } 6.5\end{array}$ & $\begin{array}{l}\text { Large Landscape Water Conservation Pro- } \\
\text { gram and Incentives } \\
\text { The City will provide assistance on improv- } \\
\text { ing water irrigation efficiency and modi- } \\
\text { fications, as well as financial incentives by } \\
\text { supplying irrigation system assessments for } \\
\text { the top water users. }\end{array}$ \\
\hline $\begin{array}{l}\text { Urban Water } \\
\text { Management Plan } \\
\text { Chapter } 6.6\end{array}$ & $\begin{array}{l}\text { High Efficiency Washing Machine Rebates } \\
\text { Program }\end{array}$ \\
\hline
\end{tabular}

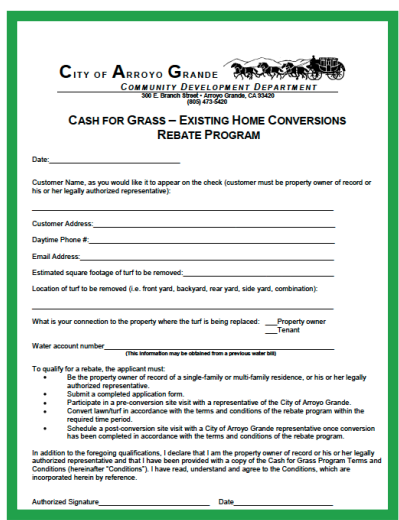

The Cash for Grass Program offers incentives for lawn removal.

\section{Implementation}

As of 2012, the Cash for Grass Program had realized a savings of 3 acre feet per year. The Residential Plumbing Retrofit Program has conserved 156 acre feet per year. The high efficiency washing machine rebates program had saved an estimated 464,482 gallons as of 2010. In addition, since 2006, high efficiency motors were installed at 5 water pumps and lift stations. 


\section{Carbon Sequestration Policies}

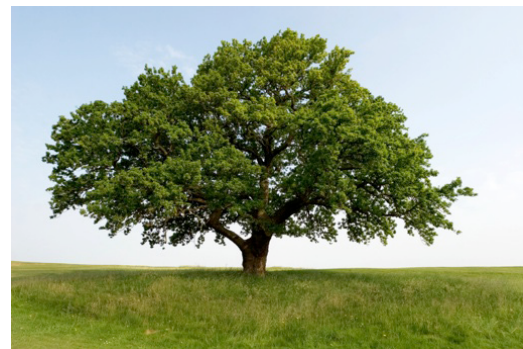

Trees absorb the most carbon during the first 20 years of their lives.
Carbon Sequestration is the capture and storage of carbon from the atmosphere. Vegetation and open space preservation can increase carbon sequestration and result in lower total GHG emissions. (See Table 20).

Table 20: Carbon Sequestration Policies

\begin{tabular}{|c|c|}
\hline Source & Title and Description \\
\hline $\begin{array}{l}\text { Land Use Ele- } \\
\text { ment }\end{array}$ & $\begin{array}{l}\text { LU12-3.3 Where construction of a solid wall } \\
\text { that will be visible along a public street is neces- } \\
\text { sary, provide landscaping such as trees, shrubs, } \\
\text { or vines to soften the appearance of the wall, } \\
\text { and to reduce undue glare, heat, and reflection. }\end{array}$ \\
\hline $\begin{array}{l}\text { Land Use Ele- } \\
\text { ment }\end{array}$ & $\begin{array}{l}\text { LU 12-8 Emphasize the incorporation of land- } \\
\text { scape themes and extensive landscaped areas } \\
\text { into new development; provide landscaping and } \\
\text { open spaces as an integral part of project design } \\
\text { to enhance building design, public views, and } \\
\text { interior spaces; provide buffers and transitions } \\
\text { as needed; and facilitate energy conservation. }\end{array}$ \\
\hline $\begin{array}{l}\text { Agriculture, } \\
\text { Conservation } \\
\text { and Open } \\
\text { Space Ele- } \\
\text { ment }\end{array}$ & $\begin{array}{l}\text { Ag1-3 Support existing programs and develop } \\
\text { strategies to retain areas of farmland soils for } \\
\text { agricultural use, and other Conservation/Open } \\
\text { Space (C/OS) areas in a natural, undeveloped } \\
\text { state. }\end{array}$ \\
\hline $\begin{array}{l}\text { Parks and } \\
\text { Recreation } \\
\text { Element }\end{array}$ & $\begin{array}{l}\text { Objective PR1 Neighborhood and community } \\
\text { park facilities, including the sports complex, } \\
\text { should be provided at a ratio of four ( } 4 \text { ) acres of } \\
\text { parkland per 1,000 residents. }\end{array}$ \\
\hline
\end{tabular}

\section{Implementation: New Trees Planted}

Trees capture and store the most carbon during the first 20 years of life. Different species of trees have different rates of carbon sequestration. Since 2006, Arroyo Grande has planted over 250 new trees of various species. According to the CAPCOA GHG Emissions Quantification Formula for Urban Tree Planting, this will result in a citywide $0.10 \% \mathrm{GHG}$ emissions reduction. 


\section{Renewable Energy Policies}

Energy generated from renewable sources, such as solar, wind, and thermal energy, produces significantly lower GHG emissions. Developing these energy sources can reduce GHG emissions.

\section{City Programs}

Although not directly related to renewable energy, the City's Green Corridor Program might help to attract businesses that support renewable energy. The City Council approved the green corridor program in 2009. The program offers rebates on licensing fees for new businesses on El Camino Real who devote a minimum of $65 \%$ of their operations and sales to:

- Alternative Fuels

- Alternative Fuel Vehicles

- Other Non-Fossil Fuel Powered Modes of Transportation

- Renewable Energy Sources (including, but not limited to, solar, wind, compressed natural gas, battery electric, tidal and biofuel)

- Recycling or Recycled Products

- Energy Conservation

- Water Conservation

- Water Quality

- Air Quality

- Organic Farming

- Green Building

The Green Corridor Program has the potential to impact multiple sources of GHG emissions, depending on the programs's successes. Energy generation from renewable sources could potentially increase if businesses catering to or promoting it take advantage of the green corridor program and make renewable energy more accessible for residents and businesses.

\section{Implementation: Solar Installations}

The California Solar Statistics website reports that solar installations in San Luis Obispo County from the California Solar Initiative Program are producing a total of $16.5 \mathrm{MW}$.

According to the City's self report on GHG Reduction Measures Implemented from 2006 to present, 11 single family solar installations have been installed community-wide through Community Development Block Grant recipient, Grid Alternatives.

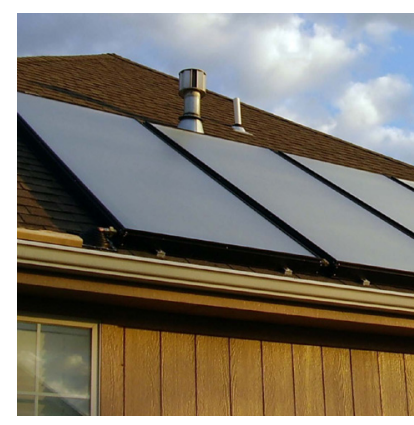

Some Arroyo Grande homeowners have installed solar panels. 


\section{Potentially Inconsistent Policies}

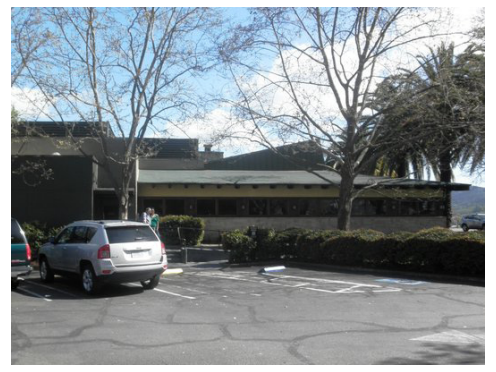

Having many parking lots in one area can encourage driving instead of walking between destinations.
Some City policies are potentially inconsistent with Arroyo Grande's future goals for emissions reductions. The identified policies either contribute to increased emissions or may inhibit implementation of policies aimed at reducing emissions. These policies should be considered for possible revision to help Arroyo Grande achieve its emissions reductions goals. In some cases adding specific implementation guidelines can help control the emissions adding potential.

\section{Transportation}

Parking lots can contribute to increased GHG emissions in two ways. Convenient parking can encourage driving, and large paved areas reserved for parking can result in more spread out land use patterns, which can make walking less convenient. In contrast, single, centrally located parking lots can help encourage drivers to make one vehicle trip instead of many while running errands in a particular area. Table 21 lists a potentially inconsistent parking policy.

Ultimately, the way this policy is implemented can determine to what extent GHG emissions are influenced. Shared parking lots can result in less space used for parking overall. Locating parking lots behind buildings can improve the pedestrian environment and subsequently encourage walking. However, this policy could result in large lots between buildings, making walking a less attractive option. Modifying this policy to specify the type and amount of parking could make it more consistent with GHG emissions reduction goals.

\section{Table 21: Inconsistent Parking Policies}

\begin{tabular}{|l|l|l|}
\hline Source & Title and Description & \\
\hline $\begin{array}{l}\text { Circulation } \\
\text { Element }\end{array}$ & $\begin{array}{l}\text { CT3-5.3 Develop adequate public or shared off- } \\
\text { street parking lots conveniently located behind } \\
\text { and beside buildings in Village Core and Mixed } \\
\text { Use Corridors, according to area design guide- } \\
\text { lines. }\end{array}$ & \\
\hline
\end{tabular}




\section{Growth Management}

Policies that limit densities and building heights can inhibit compact development patterns, and thus have the potential to increase automobile trips. Table 22 lists policies with the potential to limit densities and building heights.

Table 22: Inconsistent Growth Management Policies

\begin{tabular}{|c|c|}
\hline Source & TItle and Description \\
\hline $\begin{array}{l}\text { Land Use } \\
\text { Element }\end{array}$ & $\begin{array}{l}\text { LU11-1.1 As part of the development review pro- } \\
\text { cess, treat the densities and intensities outlined in } \\
\text { the Land Use Element as the maximum allowable; } \\
\text { do not approve the maximum allowable density or } \\
\text { intensity unless the proposed project is consistent } \\
\text { with the provisions and intent of the Arroyo Grande } \\
\text { General Plan and City ordinances. }\end{array}$ \\
\hline $\begin{array}{l}\text { Land Use } \\
\text { Element }\end{array}$ & $\begin{array}{l}\text { LU } 12-2 \text { Except for narrow, two an three-story struc- } \\
\text { tures within the Village Core and other designated } \\
\text { Mixed-Use areas, limit the scale of buildings within } \\
\text { both the urban and rural portions of Arroyo Grande } \\
\text { to low-profile, horizontal forms; design buildings to } \\
\text { be compatible with Arroyo Grande's historic small } \\
\text { town character. }\end{array}$ \\
\hline
\end{tabular}

\section{Annexation}

Although annexation policies can be consistent with GHG reduction strategies if they help promote compact development and preserve open space, annexation also brings additional area into the city's limits that was not previously counted toward the city's GHG emissions. This can result in increased GHG emissions overall. Table 23 lists annexation policies.

\section{Table 23: Inconsistent Annexation Policies}

\begin{tabular}{|c|c|}
\hline Source & Title and Description \\
\hline $\begin{array}{l}\text { Housing } \\
\text { Element }\end{array}$ & $\begin{array}{l}\text { The City may annex land on the urban edge to pro- } \\
\text { mote orderly growth and the preservation of open } \\
\text { space. }\end{array}$ \\
\hline $\begin{array}{l}\text { Land Use } \\
\text { Element }\end{array}$ & $\begin{array}{l}\text { LU11-6.10.1 The City of Arroyo Grande may con- } \\
\text { sider the annexation of the unincorporated portion } \\
\text { of the Arroyo Linda Crossroads and Williams prop- } \\
\text { erties within the proposed Sphere of Influence... }\end{array}$ \\
\hline
\end{tabular}

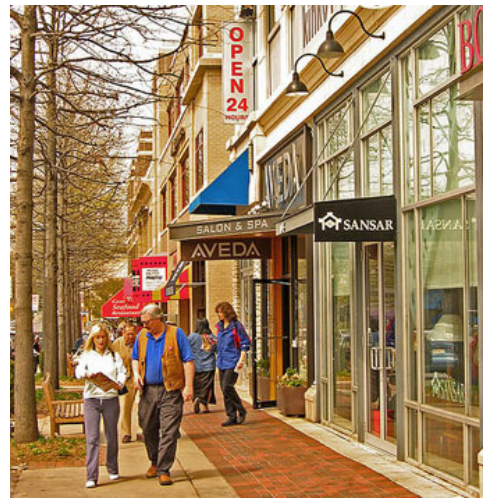

Compact development can make walking convenient and enjoyable, but limiting densities and building heights can make achieving compact development patterns difficult. 


\section{Section II:}

\section{Recommendations}

\section{Recommended Strategies for GHG Emissions Reductions}

in the City of Arroyo Grande

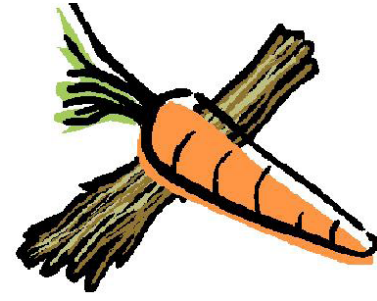

GHG reductions strategies range from voluntary, to incentive based, to mandated.

\section{Developing GHG Emissions Reduction Strategies}

Arroyo Grande must consider many factors when developing and implementing GHG emissions reductions strategies. The local climate, economy, and political context can influence which strategies are likely to be most successful. These recommendations are adapted from and/or inspired by Climate Actions Plans in other jurisdictions and best practices recommendations from local, state, and federal organizations. Strategies were chosen based on opportunity areas identified through the policy audit. Special attention has been given to those strategies that are likely to have an existing framework of support in the community or the region.

The majority of recommendations in this document focus on strategies to change behavior. Successfully reducing GHG emissions will require providing the means to alter behavior and motivating people to do so. For example, based on the policy audit analysis, Arroyo Grande is making progress toward providing infrastructure to facilitate alternative modes of transportation; however, these actions alone will not reduce emissions. Infrastructure must be combined with strategies to encourage people to change their commuting behaviors.

\section{Voluntary Actions, Mandates, and Incentives}

In Local Climate Action Planning (2012), Bosswell, Greve, and Seale explain that GHG reduction strategies take three main forms: mandates, incentives or disincentives, and voluntary actions. Mandates often have higher costs and face more political opposition, but they have higher rates of guarantees that emissions reductions will result. It is important to consider which groups will be most impacted by mandates. Incentives and disincentives can help persuade individuals or groups to take action by easing financial burdens or adding benefits for some measures. These measures often still require a significant funding source, and can still be politically sensitive. Voluntary measures are often the easiest to implement, but carry little guarantee that measurable reductions will result. A phased approach may be the most helpful in implementing politically sensitive recommendations. This begins with educational and voluntary measures and progresses to an incentive based program before finally becoming mandatory. 


\section{Strategy Recommendations List}

The GHG emissions reduction strategy recommendations listed below are detailed on the following pages. Recommendations are divided between those aimed at reducing emissions from municipal operations and those aimed at reducing emissions from communitywide sources. Recommendations are further categorized by sector.

\section{Municipal Operations}

\section{Transportation}

\section{Employee Commute}

- Appoint an Alternative Transportation Coordinator

- Set Up a Commuter Choice Program

- Start a VanPool

- Alternative Transportation Commute Challenges and Incentives

- Clean Commuter Recognition Program

- Setting Alternative Transportation Goals

- Alternative Work Schedules

- Telecommuting

- Employee Parking

- Bike Sharing Program for City Employees

Municipal Vehicle Fleet

- Track Fleet Energy Usage

- Maintain Vehicle Efficiency

- Driver Efficiency Training

- Establish a Policy Against Idling Vehicles

- Consider Lifecycle Costs when Purchasing Vehicles

- Consider the Purchase of Vehicles that Run on Alternative Fuels

- Adopt a Fuel Efficiency By-law

- $\quad$ Reduce Vehicle Miles Traveled

\section{Buildings}

- Benchmark and Track Energy Usage in Municipal Buildings

- Establish an Energy Fund to Provide Ongoing Support for Energy Efficiency and Renewable Energy Projects 


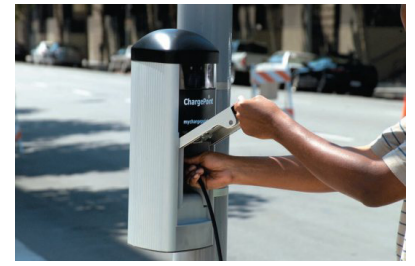

Plug-in Electric Vehicle Infrastructure is one $G H G$ emissions reduction strategy.

\section{Other Energy Efficiency}

Outdoor Lighting

- Convert city-owned streetlights to LED

- Convert outdoor lights to LED

\section{Community-Wide}

\section{Transportation}

- Encourage Employer Supported Alternative Commute Programs

- Develop a community-wide bike share or bike rental program

- Implement Parking Pricing at City-Owned Parking Lots

- Develop Plug-in Electrical Vehicle Infrastructure

\section{Buildings}

\section{Existing Buildings}

- Require Energy Efficiency Audit and Retrofits at Point of Sale or Major Renovation

- Promote Energy Conservation Among Residents and Business Owners

New Buildings

- Work With Local Chambers of Commerce and Other Local Organizations to Establish and Publicize a Unified Green Building Certification Program

\section{$\underline{\text { Renewable Energy }}$}

- Facilitate and Encourage Renewable Energy Generation 


\section{Reducing GHG Emissions from Municipal Operations}

\section{Municipal Focus}

The following recommendations focus on reducing GHG emissions from municipal operations. A large proportion of strategies recommended in this document are intended to reduce emissions from municipal operations. This is intended to maximize the relatively high level of control the City has over its own operations and the value of leading by example. Reducing emissions from municipal operations can inspire the public to take action to reduce GHG emissions in their own lives.

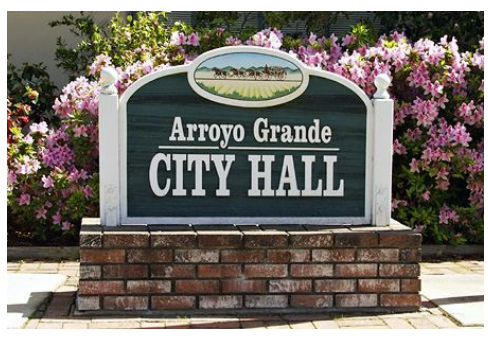

The City has the highest level of control over $G H G$ reduction strategies for municipal operations. These strategies can help set an example for the rest of the community to follow. 


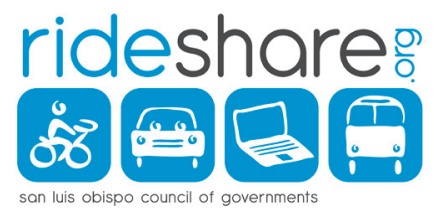

Rideshare of San Luis Obispo helps administer the Transportation Choices Program, which can help employers encourage employees to choose alternative commute options.

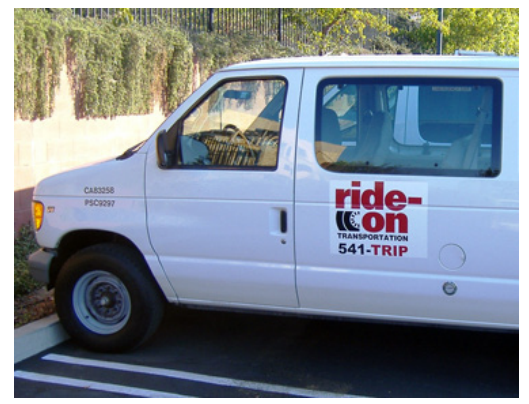

Vanpools can be a convenient way for employees to travel to and from work. Ride-on TMA offers vanpool services in San Luis Obispo County http://www.ride-on.org
Since the transportation sector accounted for $57 \%$ of communitywide GHG emissions, it is logical to give special consideration to strategies that can achieve reductions in the transportation sector. Based on review of City policies, Arroyo Grande is already in the process of developing strategies aimed at improving local transportation through the Bicycle and Trails Master Plan. Providing infrastructure is an essential component for a successful emissions reduction plan, but infrastructure alone will have little effect in the absence of behavior change. Strategies must also provide motivation and make choosing an alternative mode of transportation more convenient. Additionally, strategies must address regional commutes into the city as well as local commuting, for which walking or bicycling may be a reasonable alternative. Transportation reduction strategy recommendations in this document focus on behavior change and on reducing emissions associated with regional commutes into the City.

\section{Reducing GHG Emissions from Employee Commute}

According to the City Government Operations GHG Emissions Inventory Results, employee commute accounted for $25.5 \%$ of municipal emissions. The employee commute survey conducted in 2009 showed that employees get to and from $86.2 \%$ of their work days by driving alone. Facilitating programs that encourage employees to commute by an alternative mode, or that result in fewer commutes overall, can reduce emissions associated with this sector.

\section{Appoint an Alternative Transportation Coordinator}

Alternative commute programs can be successful and rewarding for participating employees. It can be beneficial to assign one person to take on the role of researching, coordinating, and implementing such programs. The appointed person should be someone interested in coordinating alternative transportation and will be the point of contact for communication with assisting agencies, such as the Transportation Choices Program of San Luis Obispo.

\section{Set Up a Commuter Choice Program}

The Commuter Choice Program allows employees to deduct the monthly cost of transportation (vanpool, transit pass) from their 
paychecks pre-tax. This can save employees $28-40$ percent on the costs of their commuter transportation. An employer must set up the Commuter Choice Program to allow employees to opt in. The Transportation Choices Program of San Luis Obispo can help set up the program, survey employees, and provide the forms to make the program easy for the payroll system.

Source: https://secure.buchahost.com/slotcp.org

\section{Start a VanPool}

A vanpool is a convenient way for employees to get to work without driving their own individual vehicles. Ride-on Transportation offers a start-up program where a $\$ 1,200 /$ month fee includes the maintenance and lease of a van. The 2009 employee commute survey included as part of the GHG Emissions Inventory report indicated that $0 \%$ of employees commuted by vanpool.

Starting a vanpool should begin with an employee survey to determine where their commute to work originates, and assess interest in a vanpool program. Survey results can be used to group employees who can easily commute together and provide potential vanpool participants.

\section{Alternative Transportation Commute Challenge and Incentives}

Establish a program to allow City employees to log alternative commute trips for points which can be exchanged for prizes or raffle tickets.

\section{Clean Commuter Recognition Program}

This can be used in conjunction with the Alternative Transportation Commute Challenge to recognize the employee with the highest number of alternative commute trips. This can be done on a monthly or quarterly basis. Examples of employee recognition programs include a plaque that employee names can be added to each quarter.

\section{Setting Alternative Transportation Goals}

Once a system for logging employee alternative transportation commutes is in place, the City can hold contests and reward the department with the highest number of alternative transit commute trips. Options include competition between departments, or setting department or city-wide goals with the reward of a pizza party when the goal has been reached.

http://www.rideshare.org/transportationchoicesprogram.aspx

\section{Example Programs:}

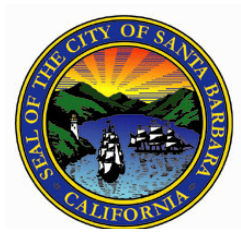

The City of Santa Barbara's alternative transportation commute challenge holds monthly drawings for \$20 gift cards to local businesses. Software such as "Greenride" can help with the process of tracking employee trips.

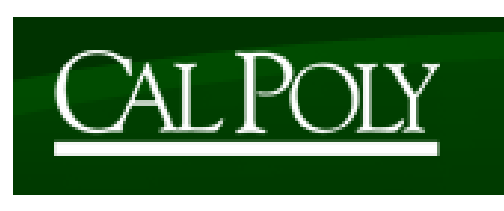

California Polytechnic State University Police Department administers a program where City employees report their alternative commute trips for the month and points are credited to a "Campus Express" account. 


\section{Case Study: Santa Barbara}

The City of Santa Barbara implemented a standard, citywide $9 / 80$ work schedule in 2007 by extending public services hours of many city offices, counters, and operations and closing on alternate Fridays.

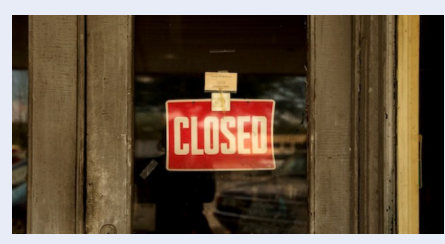

An interdepartmental staff committee surveyed similar sized agencies that had implemented $9 / 80$ work schedules. From 18 responses, the committee reported:

"Overall, the surveys found that customers reacted positively to their extended service hours; and staff morale and recruitment efforts improved with the $9 / 80$ schedule. Cities reported no negative impacts on productivity. Initially, there were some minor problems with members of the public trying to conduct business on closed Fridays and/or with staff resistance to a new schedule. Both issues were resolved, and current enthusiasm remains high at all agencies."

\section{Alternative Work Schedules}

Alternative work schedules allow employees to opt for a schedule other than the traditional $8 \mathrm{am}$ to $5 \mathrm{pm}$ Monday through Friday work schedule. A common alternative is to increase hours Monday through Thursday and eliminate all hours every other Friday. A variety of co-benefits can result from implementing an alternative work schedule program including employee work-life balance improvements and increased public service hours. GHG reductions occur mainly as a result of fewer commutes by personal vehicle when employees opt to work longer hours fewer days per month.

An unintended consequence of this strategy may be increased total hours of operation for municipal buildings. If some employees are staying later while others choose to adhere to the traditional 5 day a week schedule, total energy usage for the building may increase. Some municipalities have opted to make the switch to an alternative schedule mandatory for all or most city departments. Soliciting feedback from both employees and the public about this kind of proposed change beforehand can help the city determine if this is the right choice for Arroyo Grande.

Financial Considerations include staff time to assess feedback and impacts of strategy implementation, and materials and staff time to disseminate information to the public about the new schedule.

\section{Implementation Steps}

1) Conduct a survey of employees to assess interest and solicit feedback.

2) Communicate with other departments and municipalities to work out logistics and assess impacts.

3)Determine essential city services that must remain open, assess impact to regular deadlines and scheduling.

4) Choose a date to begin the switch to the alternate schedule.

5) Pass a resolution.

6) Inform the public.

Indicator to Measure Effectiveness

- Average vehicle miles traveled per employee per month

\section{Telecommuting}

Allowing employees the option of telecommuting on certain days can reduce emissions from employee commutes. This strategy has similar benefits and implementation needs to the alternative schedule strategy but on an individual employee basis. Telecommuting can be part of an overall strategy to reduce emissions from employee commutes. 


\section{Employee Parking}

Increasing the cost of parking can make alternative modes more cost effective alternatives to driving alone. Currently, municipal employees primarily park for free in off-street lots. Requiring employees to purchase parking passes in order to park at some facilities with the funds going to alternative commute programs could decrease emissions associated with employee commutes while raising funds for bike parking, incentive programs, vanpools, or other alternative commute programs.

\section{Expand Bike Sharing Program for City Employees}

Purchasing and maintaining more bicycles that city employees can check out to ride to meetings and appointments can reduce emissions from employee travel and promote bicycling in the community. The added convenience of being able to check out helmets and bike locks can make choosing to ride a bicycle a free and attractive alternative to driving. Additionally, this can provide a positive introduction to commuting by bicycle for employees, who might choose to use bicycling as a mode of transportation more frequently.

\section{Implementation Steps}

1) Conduct a study to assess current level of interest in the program

2) Secure funding for additional bicycle purchase and maintenance

3) Research bicycle fleet and equipment purchase options

4) Designate/construct additional bicycle storage locations

4) Create/expand system check-out process

5) Consider developing incentives to encourage program use

6) Advertise program to City employees

7) Track participation

\section{Indicator to Measure Effectiveness}

-Number of bicycle check-outs

-Reductions in miles traveled in city vehicles or personal vehicles for work-related trips

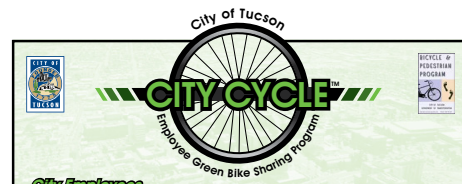

\section{SHIFT GEARS \& BIKE THEREI}

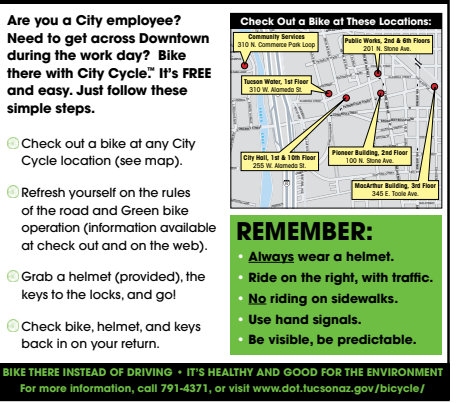

The City of Tuscon, AZ maintains an employee Cycle Program to encourage employees to bicycle to appointments. 


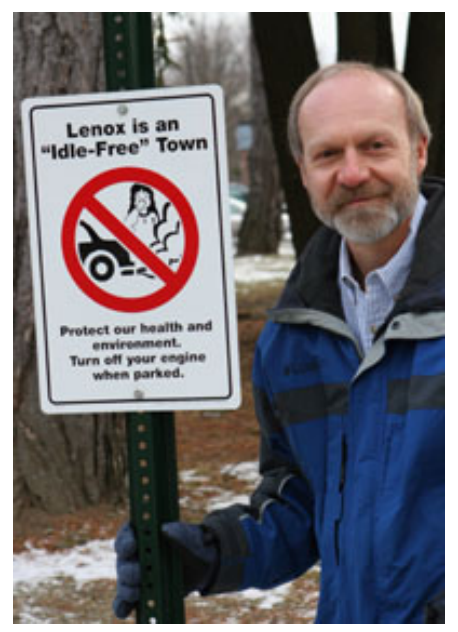

Resident Rick Gregg led an "idlefree" campaign in Lenox, MA.
Arroyo Grande's Vehicle Fleet accounted for 34.6\% of municipal operations emissions. A variety of policy and practice options can help decrease emissions associated with the operation of city vehicles. While replacement of the vehicle fleet with high efficiency or alternative fueled vehicles would require an infeasible financial investment, a strategy that incorporates fuel efficiency into the normal vehicle replacement process and seeks to reduce gasoline consumption overall can put the City on track to reduce municipal vehicle emissions over time and set an example for the community.

\section{Track Fleet Energy Usage}

Establishing and maintaining a process for tracking odometer readings and fuel usage can provide the basis for a fleet efficiency program. This data can identify the most used vehicles and the vehicles for which replacement or route changes might have the most beneficial impact. The City can better understand its specific vehicle needs and identify opportunities to improve efficiency, such as by downsizing vehicles or promoting efficient driving practices.

\section{Maintain Vehicle Efficiency}

Keeping tires properly inflated and keeping racks and tools on vehicle roofs only when necessary can help reduce fuel usage.

\section{Driver Efficiency Training}

Providing training for employees who drive City vehicles on efficient practices can save fuel and reduce emissions. Practices for efficient driving include avoiding fast acceleration, hard braking, and excessive idling. Other practices include careful trip planning to combine trips and identify efficient routes, and requiring employees to choose the right vehicle for each trip. Using a shared vehicle pool instead of assigning specific vehicles to employees can help to make sure large, less efficient vehicles are not used when a smaller vehicle could meet the day's needs. Efficiency training can be paired with tracking and rewards programs to recognize and reward employees or departments who practice driving efficiency techniques.

\section{Establish a Policy Against Idling Vehicles}

Limiting vehicle idling reduces fuel consumption. Some municipalities have developed a policy to prohibit idling for more than 5 minutes. This can be expanded to a citywide campaign to raise awareness about wasted fuel and emissions that result from idling vehicles.

\section{Consider Lifecycle Costs when Purchasing Vehicles}

Incorporating fuel efficiency and maintenance costs into vehicle purchasing decisions can help the City make more informed decisions 
about the total costs of vehicles. Resources for determining costs and benefits of fuel efficient vehicles are available online and include California's Drive Clean Guide and the EPA's Green Vehicle Guide.

http://www.driveclean.ca.gov

http://www.epa.gov/greenvehicles

\section{Consider the Purchase of Vehicles that Run on Alternative Fuels}

Rising fuel prices and uncertain fuel availability in the future can make it difficult for the City to meet its operational needs. Incorporating alternative fuel vehicles into the municipal fleet can offer greater security and reduced overall costs.

\section{Adopt a Fuel Efficiency By-law}

The City can make it a policy to purchase the most fuel efficient vehicle available that will meet the needs of the job for which the vehicle is intended. This can also be adapted to require minimum fuel efficiency standards for all vehicle purchases.

\section{Reduce Vehicle Miles Traveled}

Simply reducing overall vehicle miles traveled is an inexpensive strategy for reducing emissions from the City's vehicle fleet. Strategies include increasing telecommuting options, providing bicycles for employee travel needs, and replacing some police patrol vehicles with bicycles.

\section{Implementation Steps:}

The above measures can be implemented individually or as part of a comprehensive program to reduce emissions from the City's vehicle fleet. Suggested implementation steps for a comprehensive program are below.

1) Establish tracking system for municipal vehicle fuel use.

2) Evaluate and improve vehicle maintenance practices.

3) Develop a training program for driver efficiency.

a) Establish a team to research and develop the program.

b) Create a training schedule for existing employees.

c) Establish training requirements for new employees.

4)Establish a Policy Against Idling Vehicles.

a) Research national and state laws.

b) Develop a public awareness campaign.

5) Amend the vehicle bid process to account for life cycle costs.

6) Implement a fuel efficiency bylaw.

7) Review vehicle tracking system periodically and evaluate opportunities to downsize or eliminate vehicles.

\section{Indicators to Measure Effectiveness}

- Fuel usage of vehicles, individually and for the entire fleet

- Lifecycle costs of vehicles

\section{HAYWARD}

As part of a strategy to reduce emissions associated with the city vehicle fleet, the City of Hayward has downsized vehicle class sizes. Changes included the purchase of six compact pick-ups in leiu of full sized pickups, and replacing a full-sized van with a mini-van, and replacing full and mid-sized sedans with compact sedans.

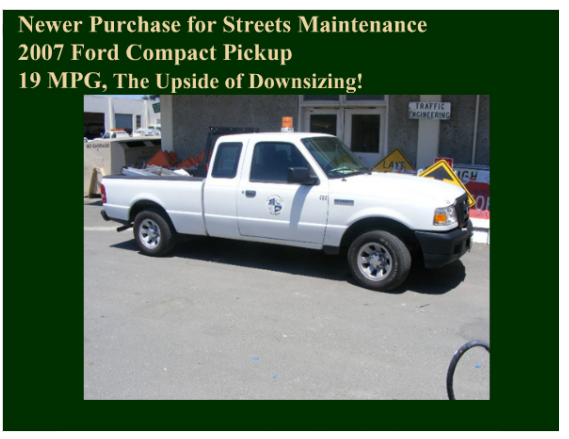




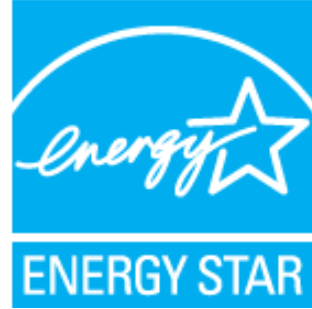

Qualified buildings can earn Energy Star Ratings, which can help a city achieve recognition for their energy efficiency successes and inspire building owners community-wide to take steps to improve energy efficiency
Reducing GHG Emissions From Municipal Buildings

Buildings and facilities account for $18.9 \%$ of city government GHG emissions. This percentage has likely decreased as a result of municipal facility retrofits completed in 2010 and 2011. Still, programs aimed at tracking and reducing GHG emissions in municipal facilities have the potential to make a significant contribution to GHG reductions.

\section{Benchmark and Track Energy Usage in Municipal Buildings}

Maintaining detailed information about building energy usage over time can help set goals and prioritize energy efficiency projects. Benchmarking provides a baseline of building energy usage and the opportunity to assess which improvements can provide the biggest payback in energy and monetary savings. This also offers a solid foundation of data to support requests for funding. An added benefit is the potential to receive an energy star performance rating as a means of showcasing energy efficiency accomplishments.

Energy Star Portfolio Manager is a free program to allow utility customers to track and assess energy usage conveniently online. Detailed utility information can be obtained from energy bills or from the utility companies directly, and is combined with building size and use characteristics. After the initial work of inputting account and building characteristic information, energy usage is entered automatically on a monthly basis by the utility companies. Assistance with setting up and managing this process is currently available for municipalities through the San Luis Obispo County Energy Watch Partnership.

Benchmarking alone will not reduce GHG emissions, but is useful in allocating resources and building support for projects that will reduce energy usage. Detailed data tracking can provide a high guarantee of emissions reduction potential. Portfolio Manager is a free software. Upfront staff time will be required to collect and input data; however, assistance from the San Luis Obispo Energy Watch Partnership can greatly lessen the amount of staff time required.

\section{Implementation Steps}

1) Sign data release forms and submit to Pacific Gas and Electric Company and SoCal Gas.

2)Obtain utility bill information.

3) Identify which facilities to benchmark.

4) Gather building characteristic information.

5) Input data into Portfolio Manager.

6) Periodically run reports and assess energy usage information.

7) Identify and prioritize energy efficiency projects. 
Indicator to Measure Effectiveness

- Number of buildings benchmarked

- Number of projects identified and completed as a result of benchmarking process

\section{Establish an Energy Fund to Provide Ongoing Support for Energy Efficiency and Renewable Energy Projects}

Like many local municipalities, one of Arroyo Grande's biggest challenges in reaching its energy goals is financing energy efficiency and renewable energy projects. Establishing an Energy Fund would capture savings from energy projects and allow them to be used to finance additional projects.

Initial funding can be supplied through grants, or through rebate checks from energy efficiency projects. Funds are replenished by predetermined sources resulting from the projects funded through the energy fund. For example, the City of San Jose's energy fund is replenished through incentives and first and second year savings resulting from retrofits of existing buildings. This is based on expected savings, not on actual utility bill reductions. Another potential source of fuding is through a surcharge on utility bills. Alameda County finances their energy program through a utility surcharge.

\section{Financial Considerations}

Establishing an Energy Fund requires initial funding to be allocated specifically to energy efficiency or renewable energy projects. Replenishment comes from the savings realized as a result of projects. Allocating these savings to the Energy Fund instead of the General Fund may limit the funding available for other projects but makes it possible to continually reinvest in energy savings and achieve overall decreases in utility bills.

Implementation Steps

1) Identify initial funding sources.

2)Develop a program plan and methods for reinvesting savings into the Energy Fund.

3)Develop Standard Operating Procedures to set procedures for transfers and deposits.

4)Develop a Memorandum of Understanding template for program customers to include cost, rebates/incentives, estimated annual savings information, and an amortization table for payments.

5)Designate responsible parties to oversee implementation.

6) Pass a resolution establishing the Energy Fund and granting authority to accept energy savings and rebates/incentives

\section{Indicators to Measure Effectiveness}

-Number of projects funded

-Total kWh savings resulting from projects funded

-Energy produced by renewable sources from projects funded

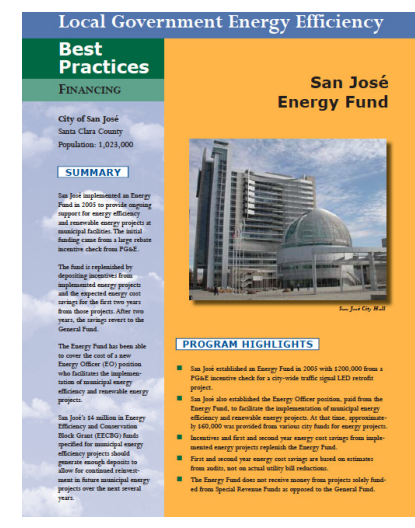

The City of San Jose implemented an Energy Fund in 2005 to provide ongoing support for energy efficiency and renewable energy projects at municipal facilities. Initial funding came from a large $P G \& E$ rebate check.

Source: Local Government Commission http://www.lgc.org 


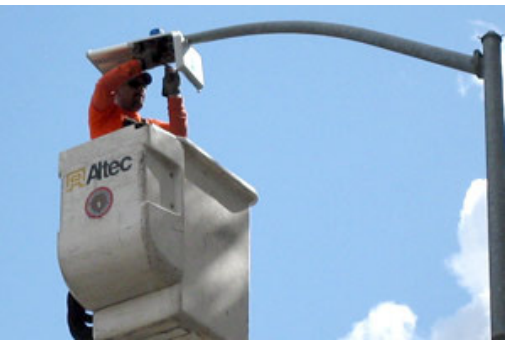

Madera County replaced 450 cityowned streetlights with LED lights. The city expects to save about $60 \%$ on the electricity used to power streetlights. This translates into about \$37,555 a year. Additionally, the County will receive $\$ 59,150$ in $P G \& E$ incentives. This will remove an estimated 154,754 pounds of greenhouse gases from the environment.

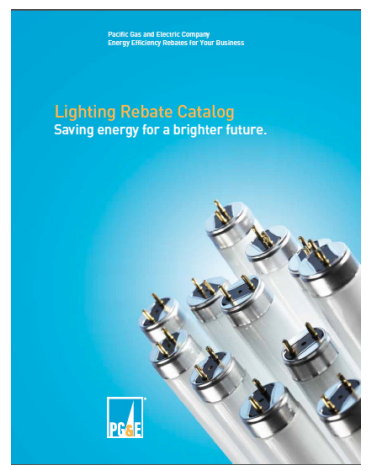

PG\&E's Lighting Rebate Catalog contains rebates for outdoor lighting fixtures.

\section{Reducing GHG Emissions From \\ Outdoor Lighting}

\section{Convert City-owned streetlights to LED}

Most of the City's streetlights are currently high pressure sodium vapor. Conversion to LED would result in significant energy savings and resulting GHG emissions reduction over the long term. Some streetlights are currently owned by PG\&E, while others are owned by the City. Conversations with PG\&E representatives revealed that the utility company is likely to pursue conversion to LED streetlights in the future.

Challenges associated with this measure include upfront cost, and improving a presently unclear database of streetlights. PG\&E representatives related that from the current database it is difficult to determine which streetlights are owned by whom. Additionally, modifications over the years have resulted in some streetlights sharing poles and electric systems with traffic signals, making savings calculations difficult.

\section{Financing}

PG\&E's LED streetlight program offers incentives for customers who replace or upgrade existing streetlights with PG\&E approved LED streetlights. Additionally, PG\&E offers a LED Streetlight Replacement service as a one-stop solution to help with purchasing and installation, disposal, and rebate application completion.

Since LED bulbs last up to 15 years longer than traditional streetlight bulbs, cost savings should also consider reduced costs from bulb replacement purchase and labor.

\section{Implementation Steps}

- Work with PG\&E to identify City-owned streetlights

- Determine funding sources and potential savings

- Decide whether to use comprehensive streetlight replacement service or replace lights individually.

\section{Indicators to Measure Effectiveness}

- Number of Streetlights Replaced

- kWh savings on energy bills

\section{Convert outdoor lights to LED}

According to City staff, Arroyo Grande owns approximately 40 to 50 lights throughout the City. Lights are located in parking lots, in Heritage Square Park, in Oolahan Alley, and on the Traffic Way bridge. Most of the lights are currently High Pressure Sodium Vapor. Conversion to LED could result in significant electricity savings.

The primary challenge to retrofitting the city's outdoor lights is the 
up front cost. Calculating the monetary savings over time that would result from the retrofits can help justify the initial costs. This project would be an ideal candidate for a revolving loan or energy fund program. PG\&E offers rebates for replacement fixtures that meet certain requirements. Details can be found at:

http://www.pge.com/mybusiness/energysavingsrebates/incentivesbyindustry/government/local/

\section{Implementation Steps}

1) Calculate potential monetary savings based on current energy bills and projected savings

2) Work with PG\&E to determine ideal lighting and fixture types and identify rebate opportunities

3) Research potential funding sources

\section{Indicator to Measure Effectiveness}

-Savings realized on electricity bills

\section{Potential GHG Emissions Reductions}

An accurate estimation of emissions reductions that would result from replacing streetlights with LED fixtures requires additional information including the number of city-owned streetlights, actual power rating of current lights, and power rating of comparable LED lights. However, the following assumption based estimation can help illustrate potential energy savings and emissions reduction potential. Table 24 shows potential CO2 reductions based on a set of listed assumptions.

Table 24 Emissions Reduction Quantification for Replacing HPS Streetlights with LED fixtures

\begin{tabular}{|l|l|l|}
\hline & $\begin{array}{l}\text { High Pressure } \\
\text { Sodium Vapor }\end{array}$ & \multicolumn{1}{|c|}{ LED } \\
\hline Power Rating (W) & $200^{\star * \star}$ & $56^{\star * * *}$ \\
\hline Power Rating (kW) & 0.25 & .056 \\
\hline Total \# Streetlights in the City & 1150 & 1150 \\
\hline Avg. \# Hours on per Day & 11 & 11 \\
\hline \# Days Streetlights are on Per Year & 356 & 365 \\
\hline Total kW Usage Per Year & 900680 & 252190 \\
\hline Total CO2 Emissions Per Year & 577646614600 & 1617410552088 \\
\hline
\end{tabular}

Potential Savings Resulting From Replacing all streetlights in Arroyo Grande with LED fixtures:

kW Per Year: 648490

Percent Reduction in CO2 Per Year: $72 \%$

Calculation Formula from CAPCOA's “Quantifying Greenhouse Mitigation Measures"

${ }^{*} k$ Wh equivalencies based on California Emissions Estimator Model rates based on location and utility provider.

${ }^{* *}$ Number of streetlights as reported by City Maintenance Yard Manager

${ }_{* * *}^{*}$ Power rating from product listed at

http://www.alibaba.com/product-gs/529885419/150_250W_high_pressure_sodium_street.html

****Power Rating from product listed

for 200W HPS lamp at http://www.dmxledlights.com/OutdoorLighting/ 


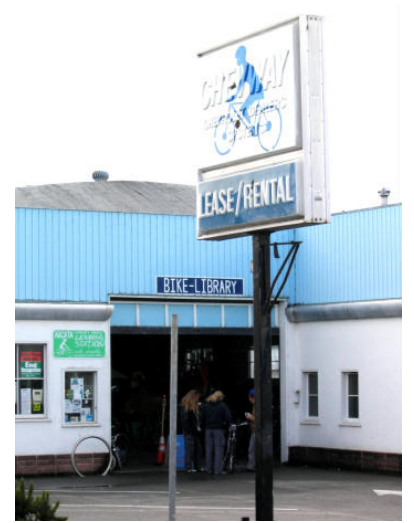

The bike library in Arcata, CA allows residents to check out a bike for up to 6 months.

\section{Encourage Employer Supported Alternative Commute Programs}

In order to reduce emissions associated with commuting both locally and into the City, Arroyo Grande can help employers learn about and implement programs to support alternative commuting. Developing and publicizing the City's own alternative commute programs can help set an example for other employers. The same options listed as strategies for reducing emissions from City employee commute are available to employers throughout the City.

\section{Implementation Steps}

1) Develop and publicize City employee alternative commute programs.

2) Distribute resources to local employers.

a) Provide case studies of successful alternative commute programs and step by step plans for implementing different options.

b)Network with the Aroyo Grande Chamber of Commerce for distribution and communication opportunities.

3) Coordinate with Rideshare and the SLO Bicycle Coalition to plan promotional events.

\section{Indicators to Measure Effectiveness}

- Number of employers participating in alternative commute programs

- Number of participating employees

- Estimated reductions in vehicle miles traveled from each participating employer 
Develop a Community-Wide Bike Share or Rental Program

Bike share programs have developed in cities across the nation as a means provide city residents with convenient, affordable access to bicycles. Generally, stations are conveniently located throughout a city and residents can check them out with a credit card. As a small town, where may residents might be commuting from primarily residential areas, Arroyo Grande might consider a longer term bike rental program. This would offer residents the ability to check out a bicycle for an extended period of time for one set fee. This option reduces program operation costs by eliminating the need for many pay stations. Residents can check out a bike, helmet, and bike lock from one location in the City, and keep it for a set period of time. This gives residents the opportunity to try bicycling without the burden of the initial investment in the bicycle and associated gear.

Purchase of a bicycle fleet, helmets, locks, and the administration and maintenance of a bike rental system can make the program costly. Funding sources should be identified early on in the process, and can include advertisements, user fees, and grants.

\section{Implementation Steps}

1) Conduct study to determine community interest and solicit feedback. Solidify program objectives and management plan.

2) Identify sponsoring agency and location. This can be either a municipal agency or a private organization. Some communities rent bikes out through their local libraries. The sponsoring agency will be responsible for management including the check out process and maintaining the bicycle fleet.

3) Develop a business plan to anticipate usage and develop a fare structure and payment methods. Determine total program costs and set fares and sponsorship fees appropriately. Determine fleet size and plan for potential program growth over time.

4) Identify additional program sponsors. Solicit advertising space on the bicycles and on promotional materials.

5) Research fleet purchase. A distinctive fleet appearance can improve awareness of the program and prevent theft. Some companies specialize in bike share programs and design bikes specifically to meet the city's needs.

\section{Indicators to Measure Effectiveness}

- Number of bicycle check outs

- Estimated number of driving trips replaced by bicycle trips

- User feedback surveys

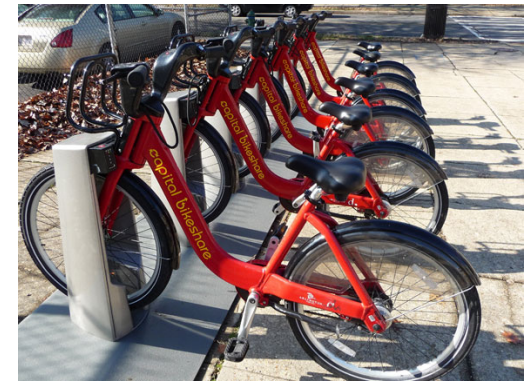

Distinctive-looking bicycles can make the City's fleet stand out and draw attention to the program. Bikes pictured are part of Washington D.C.'s fleet. (Photo from bicycling.com) 


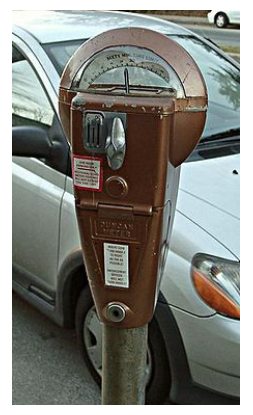

Paid parking lots increase the costs associated with driving personal vehicles.

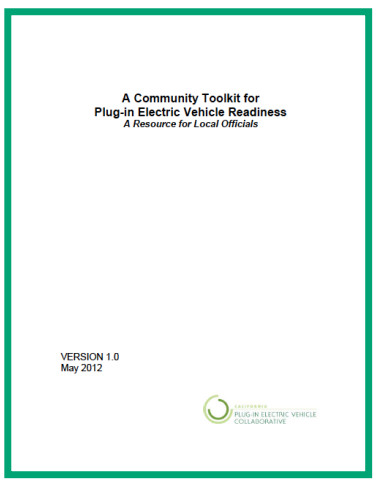

Detailed information on developing infrastructure for plug-in electric vehicles is available from the California Plug-in Electric Vehicle Collaborative's publication "A Community Toolkit for Plug-in Elevtric Vehicle Readiness: A Resource for Local Officials"

\section{Implement Parking Pricing at City-Owned Parking Lots}

Parking in City-owned lots is currently free. Implementing parking fees is a disincentive method that can increase costs associated with driving personal vehicles, and subsequently increase the relative savings that result from choosing alternative modes of transportation. Additionally, revenue collected from parking fees can be used to fund alternative transportation programs. Parking lots can allow for exceptions for certain vehicles, such as high efficiency or alternative fueled vehicles.

\section{Implementation Steps:}

1) Evaluate costs and benefits associated with parking pricing

2) Determine method of fee collection

3) Set up fund to allocate fees collected to specific areas, such as alternative transportation programs.

4) Develop public education and input campaign to raise awareness and support for the new parking fees and decide where to allocate revenue

\section{Indicators to Measure Effectiveness}

- Survey results on transportation mode choices

- Change in number of cars present in specified locations

\section{Develop Plug-in Electric Vehicle Infrastructure}

Developing infrastructure for plug-in electric vehicles (PEVs), including charging stations and parking specifically designated for these types of vehicles can make owning an electric vehicle more beneficial and convenient. This contributes to reduced GHG emissions because electric vehicles have significantly lower emissions than gasoline powered vehicles.

\section{Implementation Steps:}

1) Update building codes with specifications for installing PEV infrastructure, including charging infrastructure types and service ratings, charging infrastructure circuit specifications, and installation recommendations for various building types.

2)Develop a streamlined permitting and inspection process for new installations.

3) Conduct outreach to local businesses and residents to provide information on the benefits of PEV and how to install/use PEV infrastructure.

4) Develop a community-wide plan to identify sites and develop infrastructure.

Indicators to Measure Effectiveness:

- Number of charging stations in the city

- Number of registered electric vehicles in the city 


\section{Buildings Recommendations}

Reducing GHG Emissions From

\section{Existing Buildings}

Together, residential and commercial buildings accounted for 36.9\% of community-wide GHG emissions. Emissions from existing construction can be reduced by improving energy efficiency through retrofits and upgrades.

\section{Require Energy Efficiency Audits and/or Retrofits at Point of Sale or Major Renovation}

The Draft San Luis Obispo City Climate Action Plan and San Luis Obispo County's Energy Wise plan include strategies requiring ratings and disclosure of energy use at point of sale. Mirroring these policies would promote regional consistency in assigning value to energy efficiency in the built environment. Having a consistent policy in all jurisdictions means that Arroyo Grande will not experience an unfair disadvantage in real estate costs. If all jurisdictions have comparable policies the real estate community as a whole will become more informed on the value and importance of energy efficiency. Buyers can then make more informed decisions and property energy efficiency will be a more widely recognized, quantifiable value.

\section{Implementation Steps:}

1) Determine size of renovation that requires an audit.

2) Determine standards below which retrofits will be required.

3) Develop accessible database of standard retrofit project components and list of approved contractors to facilitate ease of complying with requirements

Indicators to Measure Progress:

- Number of audits conducted each year

- Number of buildings that receive upgrades or retrofits

\section{Promote Energy Conservation Among Residents and Business Owners}

Raising awareness of energy efficiency opportunities can be accomplished through local campaigns and programs that provide information on rebate and incentive programs, energy measuring tools and services, and the value of energy efficiency.

Implementation Steps:

1) Coordinate with local organizations and partnerships, such as SLO County Energy Watch, to conduct outreach and connect residents

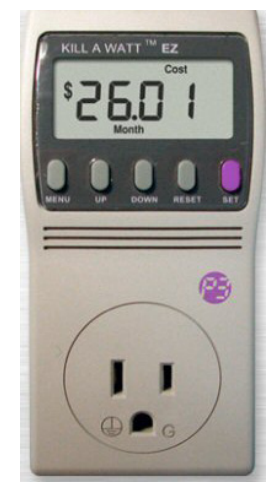

A kill-a-watt meter is a convenient tool for measuring electricity consumption of household appliances. Plugging the meter into an electrical outlet and then plugging an appliance into the meter will display electricity consumption over time and the associated monetary cost. In San Jose, residents can check meters out from local libraries. 


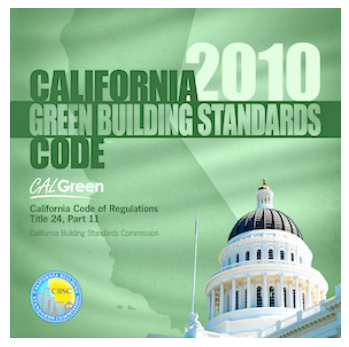

Incentives to encourage new buildings to meet or exceed minimum $\mathrm{Cal}$ Green requirements can reduce GHG emissions from buildings community-wide.
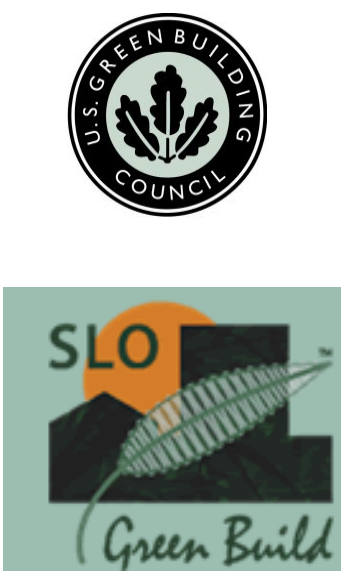

Local organizations, including the local chapter of the United States Green Building Council and SLO Green Build, can help provide the framework and stakeholder support for a green building certification program. and business owners to energy efficiency programs.

2) Provide tools and resources that facilitate energy consumption awareness and education. This can include access to online measurement tools, and maintaining tool checkout programs.

3)Promote community-wide contests for energy efficient buildings. Encourage business owners to obtain energy ratings and display results to the public. Reward owners of high performing buildings.

\section{Reducing GHG Emissions From New Buildings}

\section{Work With Local Chambers of Commerce and Other Local Or- ganizations to Establish and Publicize a Unified Green Building Certification Program}

Green building represents a whole system approach for the design, construction, and maintenance of buildings that use more sustainable materials and conserve energy and water. Establishing a Green Building Certification and Maintenance Program can encourage and incentivise the construction of these buildings and lower the GHG emissions associated with the construction and use of new buildings in Arroyo Grande. Green building programs can be voluntary, incentivised, or mandatory. The San Luis Obispo City Climate Action Plan includes a policy to expand the incentive program for buildings that exceed minimum Cal Green requirements, and San Luis Obispo County adopted draft green building ordinance. To achieve regional consistency and reduce emissions from buildings, this is an important consideration for Arroyo Grande.

\section{Implementation Steps}

1) Gather stakeholders, including representatives from different jurisdictions, architects, builders, the business community, and residents.

2) Develop and agree upon green building standards.

3) Develop incentives to encourage green building certification.

4) Establish a process to coordinate and streamline the approval process in various jurisdictions.

5) Market and publicize the program to the community.

\section{Indicators to Measure Effectiveness}

- Number of certified green buildings 


\section{Renewable Energy Recommendations}

\section{Facilitate and Encourage Renewable Energy Generation}

Developing renewable energy sources reduces GHG emissions overall and provides for a more secure energy future. Arroyo Grande's climate is well suited for the development of solar energy systems. Renewable energy development can be an effective strategy both for municipal operations and commity-wide.

\section{Financing}

The two main options for funding solar installations that cannot be paid for upfront are through loans that allow for ownership of the solar installation, and power purchase agreements (PPAs). Power Purchase Agreements require minimal upfront cost. A private company owns and installs the solar installation. In this situation the customer pays for power through its normal utility billing. This can make solar an achievable goal when the upfront costs might otherwise make solar energy generation infeasible.

\section{California Solar Initative}

The California Solar Initiative (CSI) program offers rebates for solar installations. This program is currently in its final phase, meaning that rebate rates are lowest and will not be available for much longer. Still, while funding is available it can help make solar installation more feasible for many residential and business customers.

\section{Revolving low interest loan program}

Much like the energy fund strategy recommended to finance the City's energy efficiency projects, a community revolving loan program can provide property owners with the means to finance renewable energy projects. Advantages over a free market program include low investor returns and low cost financing.

\section{Outreach}

Developing an outreach campaign can help educate the community on the benefits of solar installations and the availability of funding options.

\section{Implementation Steps}

1) Research and develop a revolving low interest loan program.

2) Work with the utility companies, solar contractors, neighboring jurisdictions, and financial institutions to develop a revolving low interest loan program.

3) Develop and implement a public outreach campaign to educate the community about renewable energy opportunities.

Indicators to Measure Effectiveness

- Number and size of renewable energy projects installed

- Number of property owners using financing programs

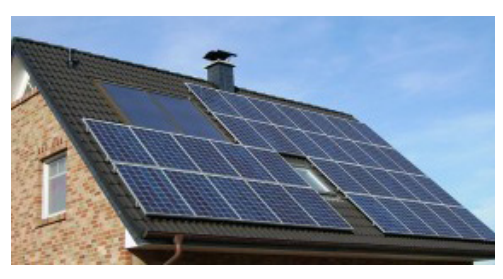

Support for the development of solar installations should include both financing and outreach programs. 


\section{Continuing the CAP Development Process}

Climate Planning in Arroyo Grande is currently being carried forward by a consultant as part of a coordinated effort between the Air Pollution Control District and several municipalities in San Luis Obispo County. The consultant's planning efforts will include updating the inventory and developing a Climate Action Plan and a toolkit for use by each community. Arroyo Grande will be able to use the toolkit to tailor strategies and implementation efforts to meet the community's specific needs.

\section{Further Development of GHG Reduction Goals and Strategies} As part of the CAP development process, Arroyo Grande will need to set official goals and targets in accordance with national and state policies and the goals of neighboring jurisdictions. Strategy recommendations provided in this document and/or in the consultant's efforts will require further development prior to implementation. Necessary additions include more detailed quantifications and financial considerations. Additional GHG reduction strategies should be developed and revised based on community input and coordination with other local jurisdictions.

\section{Coordination and Outreach}

Public outreach should play a large role in the CAP development and implementation process. Gathering community input early in the process will help build consensus on a plan that residents can understand and support. A detailed plan for community outreach should be developed to include strategies such as public meetings, surveys, and/or outreach at community events.

\section{Implementing Actions and Monitoring Progress}

A detailed implementation program will need to be developed to ensure the success of reduction strategies. The City will need to monitor progress over time by measuring progress indicators. The CAP should be periodically updated to reflect progress and changes. 


\section{References}

\section{Articles}

Basset, E. \& Shandas, V. (2010). Innovation and Climate Action Planning. Journal of the American Planning Association.

Betsill, M. M., \&Bulkeley, H. (2006). Cities and the Multilevel Governance of Global Climate Change. Global Governance, 12(2), 141-159.

Betsil, M., \&Bulkeley H. (2007). Looking Back and Thinking Ahead: A Decade of Cities and Climate Change Research. Local Environment 12 (5): 447-56.

Buchs, M., Bardsley, N., \&Duwe, S. (2011). Who bears the brunt? Distributional effects of climate change mitigation policies. Critical Social Policy, 31(2), 285-307.

Corburn, J. (2009). Cities, Climate Change and Urban Heat Island Mitigation: Localizing Global Environmental Science. Urban Studies, 46(2), 413-427.

Ellison, K. (2006). Cities take on climate change. Frontiers in Ecology \& the Environment, 4(6), 336.

Hoornweg, D., Sugar, L., \&Trejos Gómez, C. L. (2011). Cities and greenhouse gas emissions: moving forward. Environment and Urbanization, 23(1), 207 -227.doi:10.1177/0956247810392270 (From searching: "Climate Change and local government" SAGE)

Rose, A., Wei, D., Wennberg, J., \& Peterson, T. (2009). Climate Change Policy Formation in Michigan.International Regional Science Review, 32(4), 445 -465.doi:10.1177/0160017609341381.

Mazza, P. (2002). Climate Change Solutions as Economic Development: Transforming Barriers Into Drivers. Bulletin of Science, Technology \& Society, 22(2), 158 -167.doi:10.1177/0270467602022002 009.

Schreurs, M. A. (2008). From the Bottom Up. The Journal of Environment \& Development, 17(4), 343 -355.doi:10.1177/1070496508326432.

Sharp, E. B., Daley, D. M., \& Lynch, M. S. (2011). Understanding Local Adoption and Implementation of Climate Change Mitigation Policy. Urban Affairs Review, 47(3), 433 -457. doi:10.1177/1078087410392348.

\section{Books}

Boswell, M. Greve, A., Seale, T. (2012). Local Climate Action Planning. Island Press.

Shuford, S., Rynne, S., Mueller, J. (2010). Planning for a New Energy and Climate Future (PAS 558). 
APA Planning Advisory Service.

\section{Case Studies/Examples}

Cal Poly Consulting Team. (2009). Benicia Climate Action Plan Background Report.

City of Albany. (2010). City of Albany Climate Action Plan. Retrieved from http://www.albanyca. org.

City of Arroyo Grande. Arroyo Grande General Plan. Retrieved from http://www.arroyogrande. org/document-center/planning-documents/.

City of Berkeley. (2009). Climate Action Plan. Retrieved from http://www.cityofberkeley.info/climatel

City of Chicago. Climate Action Plan. Retrieved from http://www.chicagoclimateaction.org/

City of Madison, Wisconsin. (2002). Climate Protection Plan. Retrieved from http://www.cityofmadison.com/sustainability/City/documents/ccp_2002.pdf

City of San Carlos. City of San Carlos Climate Action Plan.

City of San Luis Obispo. (2011). Draft Climate Action Plan. Retrieved from www.slocool.org

County of San Luis Obispo. (2011). Energy Wise Plan (Climate Action Plan). Retrieved from http://www.slocounty.ca.gov/planning/CAP.htm?

Henson, R. (2008). The Rough Guide to Climate Change.

San Francisco Department of the Environment, San Francisco Public Utilities Commission. (2004). Climate Action Plan for San Francisco. Local Actions to Reduce Greenhouse Gas Emissions.

SLO Climate Action Plan Cal Poly Climate Team. (2009). City of San Luis Obispo Draft Climate Action Plan Policy Audit.

ICLEI International Council for Local Environmental Initiatives. Driver Education Fuel Savings Incentive Program Edmonton Canada. Retrieved from www.iclei.org.

\section{Websites}

American Planning Association. www.planning.org/research

California Climate Change Portal. www.climatechange.ca.gov 
ICLEI Local Governments For Sustainability. http://www.icleiusa.org/

Chicago Climate Action Plan. www.chicagoclimateaction.org

California Air Resources Board. http://www.arb.ca.gov and www.coolcalifornia.org.

Garfield Clean Energy. http://www.garfieldcleanenergy.org/trans-fleets.html

Local Government Commission. lgc.org.

San Luis Obispo Council of Governments. Rideshare.org

\section{Other/Government Documents}

California Air Pollution Control Officers Association. (2010). Quantifying Greenhouse Gas Mitigation Measures. Retrieved from http://www.capcoa.org/.

California Air Pollution Control Officers Association. (2009). Model Policies for Greenhouse Gasses in General Plans. http://www.capcoa.org/.

California Natural Resources Agency. (2009). 2009 California Climate Adaptation Strategy. www. climatechange.ca.gov/adaptation

City of Arroyo Grande. Cash for Grass Existing Home Conversions Rebate Program Application.

City of Arroyo Grande. (2010). Community-Wide and Government Operations 2005 Baseline Greenhouse Gas Emissions Inventory.

Climate Wise. (2010). Integrated Climate Change Adaptation Planning in San Luis Obispo County.

ICLEI International Council for Local Environmental Initiatives. Edmonton Canada, Driver Education Fuel Savings Incentive Program. Retrieved from http://www.iclei.org.

ICLEI Local Governments for Sustainability, Cities for Climate Protection Milestone Guide.

Local Government Commission. Local Government Energy Efficiency Best Practices: Financing San Jose Energy Fund. Retrieved from lgc.org

City of Santa Barbara. Council Agenda Report Citywide 9/80 Schedule. (2007). Retrieved from http://www.santabarbaraca.gov/Government/SustainableSB/Energy_Management/9-80_Schedule. htm

California Plug-in Electric Vehicle Collaborative. (May 2012). A Community Toolkit for Plug-in Electric Vehicle Readiness: A Resource for Local Officials 
